\title{
Improvement of drought tolerance in rice using line $X$ tester mating design and biochemical molecular markers
}

\author{
Almoataz Bellah Ali El-Mouhamady ${ }^{1 *}$, Abdul Aziz M. Gad² and Ghada S. A. Abdel Karim²
}

\begin{abstract}
Background: Water stress, specifically the limited water resources needed to grow strategic crops, especially rice, poses a great threat to crop productivity. So, it was imperative that scientists all work together to try genetically improving the rice for drought tolerance in light of these environmental challenges. The aim of this study is trying to know the genetic behavior responsible for water-deficit tolerance in rice genotypes but at the molecular level. Moreover, this attempt will be an important leap in the process of genetic improvement in rice for water stress tolerance in Egypt.

Results: Twenty-three rice genotypes including eight parents and their fifteen F1 crosses or (the first hybrid generation) by line $\mathrm{X}$ tester analysis were evaluated for water stress tolerance during two experiments (the control and drought experiment) besides some molecular-biochemical studies for eight parents and the highest selected five crosses for water stress tolerance. The research revealed that five rice crosses out of fifteen hybrids were highly tolerant to water stress compared to the normal conditions. Data of biochemical markers indicated the presence of bands that are considered as molecular genetic markers for water-deficit tolerance in some rice genotypes, and this is the scientific progress achieved in this research. This was evident by increasing the density and concentration of SDSprotein electrophoresis besides enhancing the activities of peroxidase (POD) and polyphenol oxidase (PPO) under water-deficit conditions, which confirmed the tolerance of drought stress in the eight rice genotypes and the best five crosses from the first hybrid generation.

Conclusion: The five promising and superior rice hybrids showed an unparalleled tolerance to water stress in all evaluated traits under water stress treatment compared to the standard experiment. Also, biochemical and molecular parameters evidence confirmed the existence of unquestionable evidence that it represents the main nucleus for producing rice lines tolerated for drought stress under Egyptian conditions.
\end{abstract}

Kew words: Rice, Water stress tolerance, Line X tester analysis and biochemical-molecular markers

\section{Background}

Rice is considered one of the most important strategic crops for the majority of the world's population and a vital food and the main source of dry matter in developing

\footnotetext{
*Correspondence: moaatazelmohamady@gmail.com; elmouhamady@yahoo. com

${ }^{1}$ Genetics and Cytology Department, Biotechnology Research Institute, National Research Centre, 33 El Buhouth ST, Cairo 12622, Dokki, Egypt Full list of author information is available at the end of the article
}

countries, especially Egypt. Today, rice production takes place only in the delta of the Nile River because of limited water resources. Thus, the government of Egypt has tried to limit the cultivated area. Therefore, the problem of irrigation water limited in Egypt is considered a serious environmental constraint which results in the decline of rice areas that were to be planted (El-Mouhamady 2009). Moreover, Egypt's share of the Blue Nile water may decline in the coming years because of the construction of the Ethiopian Renaissance Dam. In fact, the rice 
plant is already sensitive to water stress. After all, it was presented with problems and risks due to drought stress or the limited irrigation water needed to grow rice. It became inevitable for scientists to try to devise water stress-tolerant rice lines through traditional plant breeding programs and genetic engineering and biotechnology techniques (Melandri et al. 2020). Rice genotypes such as Sakha 103, IET1444 and IET1444 x Giza 178 exhibited high averages in some agro-morphological traits of normal and drought conditions (El-Mouhamady 2009). Eldessouky et al. (2016) confirmed that some promising rice accessions exhibited high limit of water stress tolerance when evaluated under the control and stress experiment through estimated some agro-morphological traits. Singh et al. (2018) confirmed that selection based on stress tolerance indices like water stress tolerance efficiency, stress susceptibility index, stress tolerance index and stress tolerance level will result in identification of drought-tolerant accessions for rainfed ecosystem. The limit of water stress resistance capacity of a plant depends on the presence and efficiency of water-deficit adaptation mechanisms within its genome (Kim et al. 2020). Melandri et al. (2020) highlighted new breeding objectives for developing rice yielding stability under water-deficit conditions through evaluating 292 rice genotypes under field experiments in IRRI. Generally, there are two types of proteins that are originated in response to drought tolerance: functional and regulatory proteins (Oono et al. 2006; Feki et al. 2017). Moreover, drought stress causing stomata closure not only decreases water loss, but also limits $\mathrm{CO}_{2}$ diffusion into the intercellular spaces of leaves, leading to the elevated generation of reactive oxygen species (ROS) (Suzuki et al. 2012; Noctor et al. 2014; Melandri et al. 2020). Plants have developed a complex antioxidant system from enzymatic and non-enzymatic antioxidants to repair the oxidative damage caused by ROS (Ashraf 2009). Superoxide dismutase (SOD), catalase (CAT), polyphenol oxidase (PPO), glutathione reductase (GSH), peroxidase (POD) and ascorbate peroxidase represent major enzymatic antioxidants, whereas the main non-enzymatic antioxidants include ascorbic acid, $\alpha$-tocopherol, carotenoids and glutathione (Mittler 2017). The non-enzymatic antioxidants are very important as they include phenolics and flavonoids, which not only defend plants against oxidative damage, but also they are useful in the treatment of various human diseases as a result of their medicinal properties (Bozin et al. 2008; ElSayed et al. 2019). After all that was presented in detail in this regard, we can briefly mention the aim of this investigation. It is an attempt to improve genetically water stress tolerance in rice plants in light of the water poverty, in addition to the development of drought-resistant rice lines by traditional plant breeding methods as well as modern scientific approaches in the field of molecular genetics.

\section{Methods \\ Materials used in this study}

The recent study was conducted in Sakha City Farm, Kafr El Sheikh Governorate, during 2018 and 2019 seasons. Eight rice entries with different reactions for water stress tolerance were used through line $\mathrm{X}$ tester mating design. The cultivars GZ 1368-S-5-4, Agami and Gaori were testers, while the cultivars were Sakha 101, Sakha 102, Sakha 103, Giza 172 and Giza 177 which were used as lines and are listed in Table 1, respectively.

The parental genotypes were grown in three planting dates with a time difference of up to 10 days to overcome the differences in flowering among parents. Thirty-dayold seedlings of each parent were individually transplanted in the field in ten rows. Each row is $5 \mathrm{~m}$ long and includes 25 hills. At flowering time, a hybridization process among parents was conducted and the aforementioned fifteen crosses were produced in the summer season of 2018. In season 2019, parents and their 15 F1 crosses were grown under two levels of irrigation. The first level was normal irrigation conditions of continuous flooding, while the second level was flash irrigation every 10 days without any standing water. The stress experiment was applied 2 weeks after transplanting till harvesting. Individual plants of each genotype were transplanted in two rows of one meter long with $20 \mathrm{~cm}$ between hills (thirty plants for each entry) and replicated three times in a randomized complete block design (RCBD) for each treatment. The package of all other recommendations of rice sowing was followed in the same season (2019).

Note: Each irrigation experiment was a completely independent experiment and completely isolated from the other experiment. As the isolation distance was 300 $\mathrm{m}^{2}$, this buffer distance was covered with linoleum on both sides to prevent water infiltration from the standard

Table 1 Various reactions for drought tolerance in the eight rice accessions

\begin{tabular}{llll}
\hline Entries & Name & $\begin{array}{l}\text { Response to water } \\
\text { stress }\end{array}$ & Origin \\
\hline Line 1 & Sakha 101 & Moderate & Egypt \\
Line 2 & Sakha 102 & Moderate & Egypt \\
Line 3 & Sakha 103 & Moderate & Egypt \\
Line 4 & Giza 172 & Moderate & Egypt \\
Line 5 & Giza 177 & Moderate & Egypt \\
Tester 1 & GZ1368-S-5-4 & Tolerance & Egypt \\
Tester 2 & Agami & Tolerance & Egypt \\
Tester 3 & Gaori & Tolerance & Egypt \\
\hline
\end{tabular}


experiment to drought experiment. The length of each replicate of each experiment was $20 \mathrm{~m}$, and the space among each two plants was $20 \mathrm{~cm}$ into each replicate.

\section{Attributes evaluated}

Sixty guarded plants were taken from each genotype for each treatment at random to evaluate the following traits:

1. Heading date (days), 2. plant height $(\mathrm{cm}), 3$. number of filled grains per panicle, 4. 1000-grain weight (g), 5. grain yield per plant $(\mathrm{g}), 6$. maximum root length $(\mathrm{cm}), 7$. number of roots per plant, 8 . root volume, 9. root xylem vessel number, and 10. osmotic adjustment: It was determined by the formula of Morgan (1980).

\section{Statistical analysis}

It was done through the formula of IRRI (2005); heterosis and both types of combining ability effects (GCA and SCA) were calculated by Wyanne et al. (1970) and Virmani et al. (1997) as follows:

$$
\text { Heterosis over the better parent } \%=\frac{\bar{F}_{1}-\bar{B} \cdot \bar{P}}{\bar{B} \cdot \bar{P}} \times 100
$$

where $\overline{\mathrm{F}}_{1}=$ mean value of the first generation. $\bar{B} \cdot \bar{P} .=$ mean value of the better parent.

L.S.D. values were calculated to test the significance of the heterosis effects, according to the following formula suggested by Wyanne et al. (1970):

L.S.D. for better parent heterosis $=\mathrm{t} \sqrt{\frac{2 \mathrm{MSe}}{\mathrm{r}}}$

\section{Estimation of combining ability effects}

The analysis of variance for line $\mathrm{x}$ tester design including parents and crosses was computed according to Kempthorne (1957):

$$
\begin{aligned}
& \mathrm{GCA}_{L}=\frac{Y_{i . .}}{\operatorname{Tr}}-\frac{Y_{. .}}{\mathrm{LTr}} \\
& \mathrm{GCA}_{T}=\frac{\sum Y_{. j .}}{\mathrm{Lr}}-\frac{Y_{. .}}{\mathrm{LTr}} \\
& \mathrm{SCA}=\frac{Y_{i j .}}{r}-\frac{Y_{i . .}}{\operatorname{Tr}}-\frac{Y_{. j .}}{\mathrm{Lr}}-\frac{Y_{. .}}{\mathrm{LTr}}
\end{aligned}
$$

where $Y_{i . .}=$ total of $i$ th line over testers. $Y_{. .}=$grand total. $Y_{. j .}=$ total of $j_{\text {th }}$ tester over lines. $Y_{i j}=$ value of $i_{t h}$ line with $j_{\text {th }}$ tester. $\mathrm{L}, \mathrm{T}, \mathrm{r}=$ number of lines, testers and replications, respectively. L.S.D. values were calculated according to Wyanne et al. (1970) as follows:

$$
\text { L.S.D. }=t \times \sqrt{2 \mathrm{MSe} / r}
$$

\section{Molecular and biochemical studies}

Since the problem of water stress is one of the most serious problems, its impact on the biochemical processes of the plant must be studied carefully. It was observed that the assessment of morphological and physiological traits alone is not sufficient to study the matter. But the estimation of some biochemical parameters such as SDS-protein electrophoresis besides estimating the activities of peroxidase (POD) and polyphenol oxidase (PPO) enzymes had the greatest impact to know the full effect of drought stress on the growth and productivity of the rice crop. Therefore, these biochemical tests were performed on 13 rice genotypes under studying (the eight parents and the highest five crosses from the first hybrid generation for water stress tolerance) measurement with the data of all agro-morphological and physiological traits, and they are as follows: 1: Sakha 101, 2: Sakha 102, 3: Sakha 103, 4: Giza 172, 5: Giza 177, 6: GZ1364-S-5-4, 7: Agami, 8: Gaori, 9: Sakha 101 X GZ1368-S-5-4, 10: Sakha 102 X Gaori, 11: Sakha 103 X Gaori, 12: Giza 172 X Gaori and 13: Giza 177 X GZ1368-S-5-4, respectively.

2'-azino-di-(3-ethyl-benzothiazole-6-sulfonic acid) diammonium salt (ABTS), purity $<98 \%$, hydrogen peroxide of analytical grade (30\% w/v), 1-chloro-2, 4- dinitrobenzene (CDNB), reduced glutathione (GSH), benzidine dihydrochloride, sulfanilic acid and catechol are the products of Sigma-Aldrich Co. All the chemicals and reagents used were of analytical grade.

\section{Protein determination}

Protein concentration was measured by the Bio-Rad (Bradford 1976) assay using bovine serum albumin as a standard. Measurements were taken on Shimadzu UV spectrophotometer at $595 \mathrm{~nm}$.

\section{SDS-protein electrophoresis}

Sodium dodecyl sulfate polyacrylamide gel electrophoresis (SDS-PAGE) was used to study the protein banding patterns of the three lentil genotypes under the control and ethyl methanesulfonate (EMS) treatments. Protein fractionation was performed according to the method of Laemmli (1970) as modified by Studier (1973).

\section{Preparation of crude homogenate}

Fresh plant tissue $(2 \mathrm{~g})$ was pulverized in a mortar using liquid nitrogen and then homogenized in $6 \mathrm{ml}$ of $50 \mathrm{mM}$ cold Tris $-\mathrm{HCl}$ buffer, $\mathrm{pH} \mathrm{7,} \mathrm{containing} 2 \mathrm{mM}$ $\beta$-mercaptoethanol. The homogenates were centrifuged at $10,000 \mathrm{rpm}$ for $20 \mathrm{~min}$, and the supernatant was used as a crude material for enzymatic assays. 


\section{Enzyme assays}

Peroxidase (POD) and polyphenol oxidase (PPO)

Peroxidase (POD) and polyphenol oxidase (PPO) were determined according to the method of Childs and Bardsley (1975) and Kar and Mishra (1976), respectively.

\section{Glutathione S-transferase (GST)}

Glutathione S-transferase (GST) was described by Habig et al. (1974).

\section{Isozymes electrophoresis}

Native polyacrylamide gel electrophoresis (Native-PAGE) was conducted according to Stegemann et al. (1985) to identify isozyme variations between controls and EMS treatments of three lentil genotypes. Two isozymes systems such as peroxidase and polyphenol oxidase were analyzed. After electrophoresis, gels were stained according to their enzyme systems with the appropriate substrate and chemical solutions and then incubated at room temperature in dark for complete staining. For peroxidase, benzidine dihydrochloride of $0.125 \mathrm{gm}$ and $2 \mathrm{ml}$ glacial acetic acid were mixed with distilled water up to $50 \mathrm{ml}$. Gel was placed into this solution, and five drops of hydrogen peroxide were added. The gel was incubated at room temperature until bands appear (Brown 1978; Manchenko 2002). For polyphenol oxidase, $100 \mathrm{ml}$ of sodium phosphate buffer $0.1 \mathrm{M}$ at $\mathrm{pH} 6.8,15 \mathrm{mg}$ catechol and $50 \mathrm{mg}$ sulfanilic acid were used. The gel was placed into this solution and incubated at $30{ }^{\circ} \mathrm{C}$ for 30 min until bands appeared.

\section{Results}

\section{Analysis of variance}

All genotypes viewed in Table 1 exhibited high moral differences in both experiments for all attributes evaluated (Table 2). These scores included the impact of various drought treatments in ten characters of rice accessions, as well as detected highly significant variations among all sources of variation (SOV) of line $\mathrm{X}$ tester analysis for all studied traits under both treatments. The previous fact confirms that additive and additive $\mathrm{X}$ additive variations played an effective function in the genetic controlling and inheriting water stress tolerance in rice.

\section{Mean performance}

The data presented in Table 3 confirmed that the testers (TI, T2 and T3) and the crosses (L1 X T1, L2 X T3, L3 $\mathrm{X}$ T3, L4 X T3 and L5 X T1) recorded the highest averages in all attributes estimated for both experiments and exhibited high trend of drought tolerance in this regard. The previous superior rice accessions (TI, T2 and T3) and the crosses (L1 X T1, L2 X T3, L3 X T3, L4 X T3 and L5 X T1) besides the cross (L5 X T2) were recorded the highest mean values for grain yield per plant under both experiments, and the average data were as follows: $38.02 \& 29.79 \mathrm{gm}, 46.92 \& 33.57 \mathrm{gm}, 40.18$ \& $37.72 \mathrm{gm}$, $68.12 \& 57.03$ gm, $69.45 \& 51.77 \mathrm{gm}, 57.18$ \& $48.03 \mathrm{gm}$, $60.38 \& 52.06 \mathrm{gm}, 77.14 \& 63.27 \mathrm{gm}$ and $53.46 \& 44.12$ gm, respectively.

\section{Heterosis over better parent}

In Table 4, the crosses (L1 X T1, L2 X T3, L3 X T3, L4 X T3 and L5 X T1) recorded significant and highly significant negative values of heterosis over better parent under both treatments for the traits such as heading date, plant height and osmotic adjustment. However, the crosses (L1 X T1, L1 X T2, L1 X T3, L2 X T3, L3 X T3, L4 X T1, L4 X T3 and L5 X T1) under both treatments for a number of filled grains/panicles and the same genotypes for the two experiments except the crosses (L1 X T3 and L4 $\mathrm{X}$ T1) under the same treatments besides and the cross (L4 X T2) under both conditions for 1000-grain weight exhibited significant and highly significant positive values for heterosis over better parent, respectively. Also, the crosses L1 X T1, L2 X T3, L3 X T3, L4 X T3, L5 X T1 and L5 X T2 for grain yield/plant trait under both conditions, the crosses L1 X T1, L2 X T3, L3 X T3, L4 X T3 and L5 X $\mathrm{T} 1$ for maximum root length and number of roots/plant traits under normal and drought conditions besides, and the crosses L1 X T1, L1 X T3, L2 X T1, L2 X T3, L3 X T1, L3 X T2, L3 X T3, L4 X T3 and L5 X T1 for root volume and root xylem vessel number traits under both treatments exhibited significant and highly significant positive values of heterosis over better parent, respectively.

\section{General and specific combining ability effects}

Results obtained in Table 5 revealed that the genotypes line 3 , tester 1 and tester 2 had highly significant negative or positive GCA effects (desirable) for all studied traits under the normal and water stress conditions. As for the crosses, the crosses L1 X T1, L2 X T3, L3 X T3, L4 X T3 and L5 X T1 for all studied traits showed highly significant SCA effects in desired reaction (negative or positive) in both the normal and water stress conditions, as given in Table 6.

\section{Molecular and biochemical studies Protein electrophoretic pattern}

Table 7 and Fig. 1 display a total of 6 bands with different MWs ranging from 17 to $70 \mathrm{KDa}$ under normal conditions. All genotypes exhibit a low intense band with $\mathrm{MW}$ 70, except the genotypes L1 X T1, L2 X T3 and L3 X T3. The highest five hybrid genotypes L1 X T1, L2 X T3, L3 X T3, L4 X T3 and L5 X T1 exhibit a sharp band with MWs 49 and 52, where these bands are absent in parent 1 to parent 8. A sharp band with MW $35 \mathrm{KDa}$ was detected 


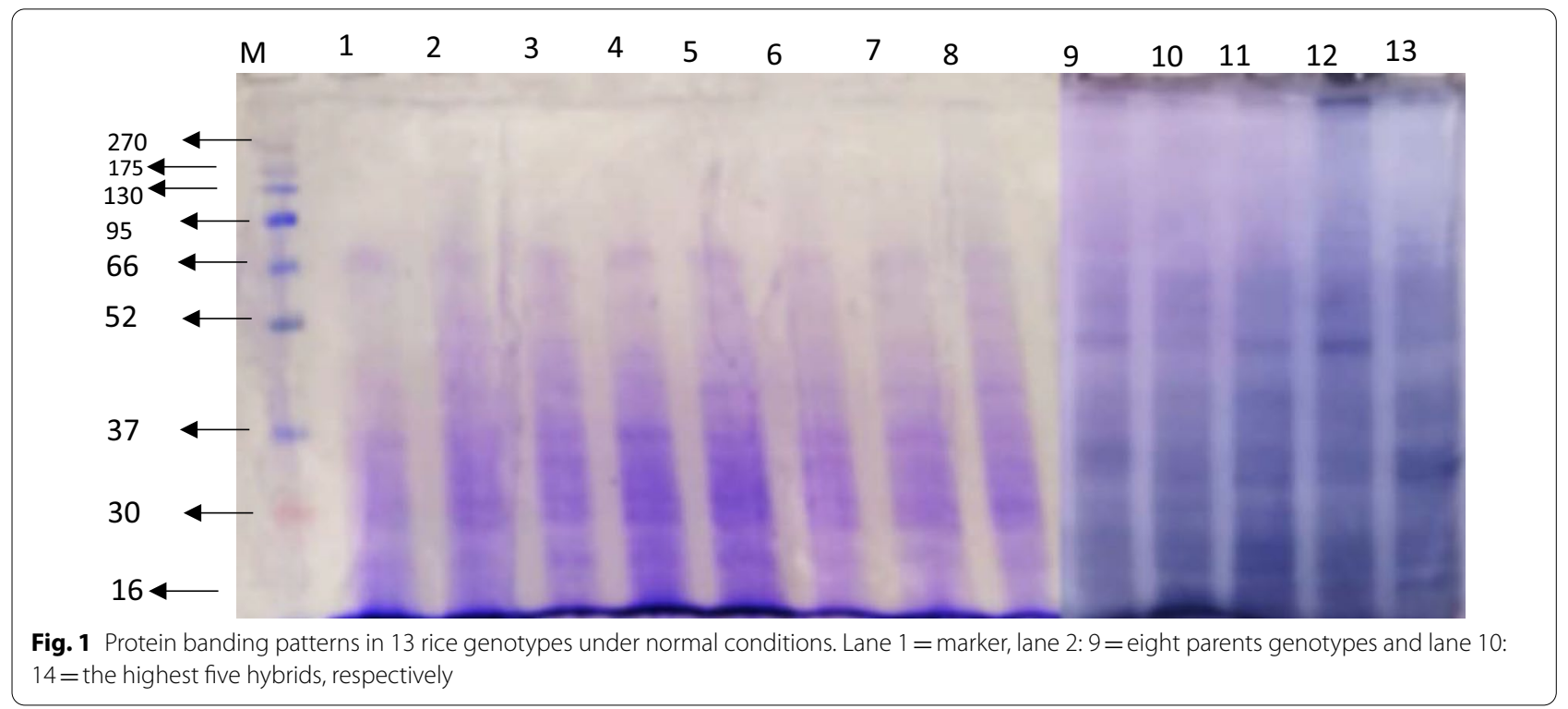

in the highest five hybrid genotypes, but its intensity decreases in genotypes from parent 1 to parent 8. Protein bands with MW of about 30 and $17 \mathrm{KDa}$ showed the same trend. All in all, the highest five hybrid genotypes L1 X T1, L2 X T3, L3 X T3, L4 X T3 and L5 X T1 show the highest intensity of bands from (1) line 1 to (6) tester 1.

Table 8 and Fig. 2 show a total of 6 bands with different MWs ranging from 26 to $95 \mathrm{KDa}$ under drought stress conditions. All genotypes exhibit a slight band with MW $95 \mathrm{KDa}$ and an intense one with MW 55 $\mathrm{KDa}$. A clear band with MW $48 \mathrm{KDa}$ was detected in all genotypes except for the genotypes L1, T2, L1 X T1and L5 X T1. Bands with MWs 36, 34 and $26 \mathrm{KDa}$ are present in all genotypes with a remarkable high intensity with a band of MW $26 \mathrm{KDa}$. From the above results, it is concluded that low molecular weight proteins which are located at the bottom of the gel have been intensified, while high molecular weight proteins which are located at the above of the gel have been weakened.

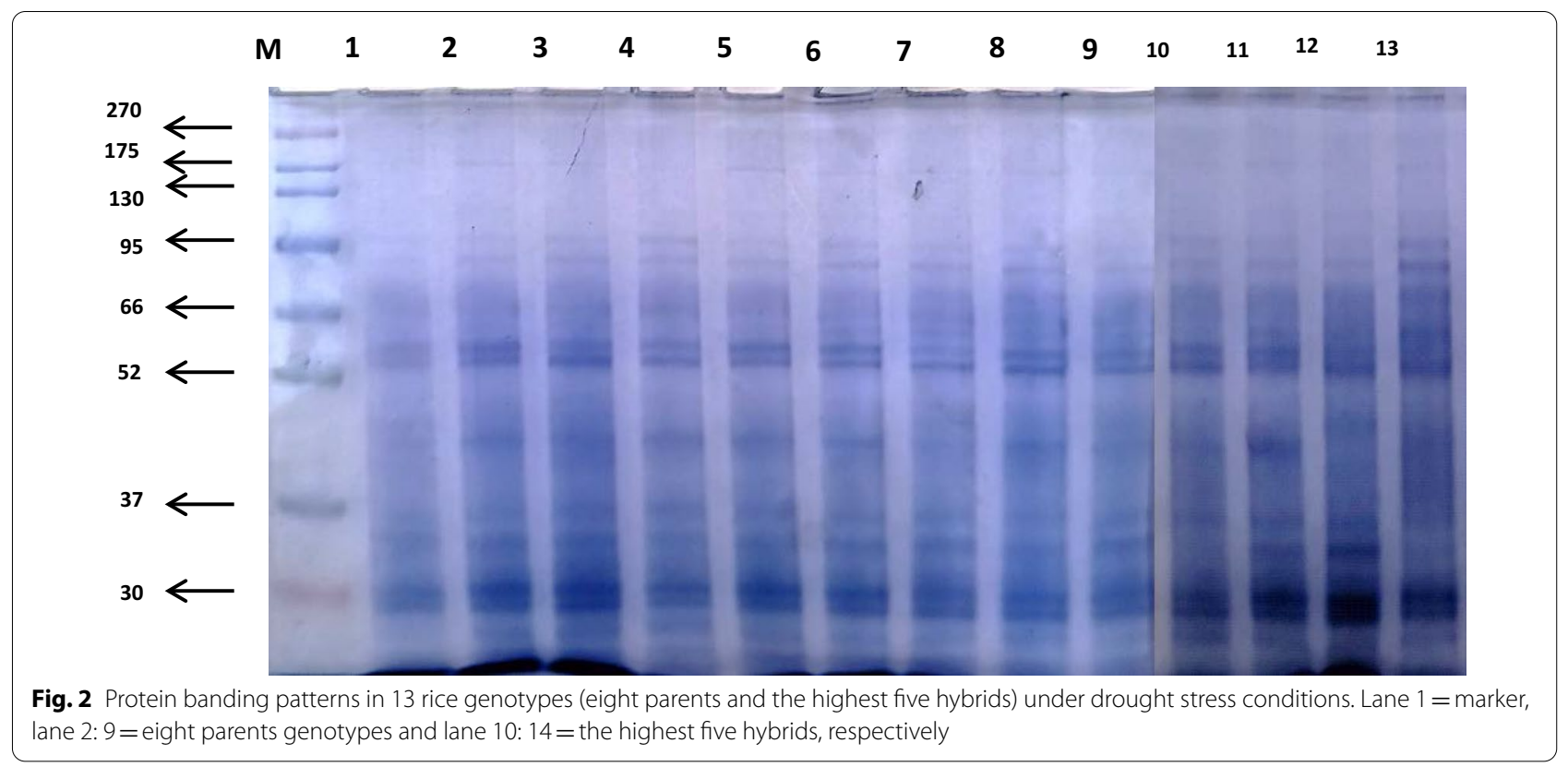


Effect of drought stress conditions on antioxidant enzymes in 13 rice genotypes

Under normal conditions, polyphenol oxidase (PPO), glutathione s-transferase (GST) and peroxidase (POD)-specific activities ranged from $0.045 \pm 0.002$ to $0.1 \pm 0.01,0.05 \pm 0.007$ to $0.19 \pm 0.03$ and $0.007 \pm 0.001$ to $0.025 \pm 0.003 \mathrm{unit} / \mathrm{mg}$ protein, for all rice genotypes. Under desiccation compression conditions, the activities of antioxidant enzymes and partaking in the scavenging of ROS increased almost to double for PPO and GST with specific activities that ranged from $0.084 \pm 0.004$ to $0.19 \pm 0.01$ and $0.17 \pm 0.02$ to $0.37 \pm 0.014$ unit $/ \mathrm{mg}$ protein for all rice genotypes. A drastic increase was observed in POD-specific activity which ranged between $0.15 \pm 0.02$ and $0.36 \pm 0.023 \mathrm{unit} / \mathrm{mg}$ protein for all rice genotypes when compared with the normal conditions.

\section{Antioxidant isozymes electrophoresis}

\section{Polyphenol oxidase (PPO) isozymes}

Under normal conditions, only one major band for various intensities can be revealed for PPO in all rice genotypes (Fig. 3 and Table 9), while, under drought stress conditions, additionally three major bands were viewed with a gradual accretion in their intensities until genotype number 10 (L2 X T3), whereas they were completely absent in the last three rice genotypes L3 X T3, L4 X T3 and L5 X T1 (Fig. 4 and Table 9). The increase in band intensity and manifestation of novel fragments may be a signal for increasing PPO activity under drought conditions.

\section{Peroxidase (POD) isozymes}

Under normal conditions, only one sharp band can be detected for all rice genotypes except for T1 and L1 X T1 genotypes (Fig. 5 and Table 10), while, under drought stress conditions, one band appeared for each rice genotype with a marked thick band for the last four rice genotypes L2 X T3, L3 X T3, L4 X T3 and L5 X T1 (Fig. 6 and Table 10). This observation may be due to severe drought conditions which in turn induce POD to reach its ultimate vigor for neutralization of ROS released beneath thirst stress treatment.

\section{Discussion}

Results shown in Table 2 gave a clear indication of the importance for successful genetic interaction obtained from line X tester analysis. The testers were credited with sifting and sorting all rice lines for drought tolerance. It
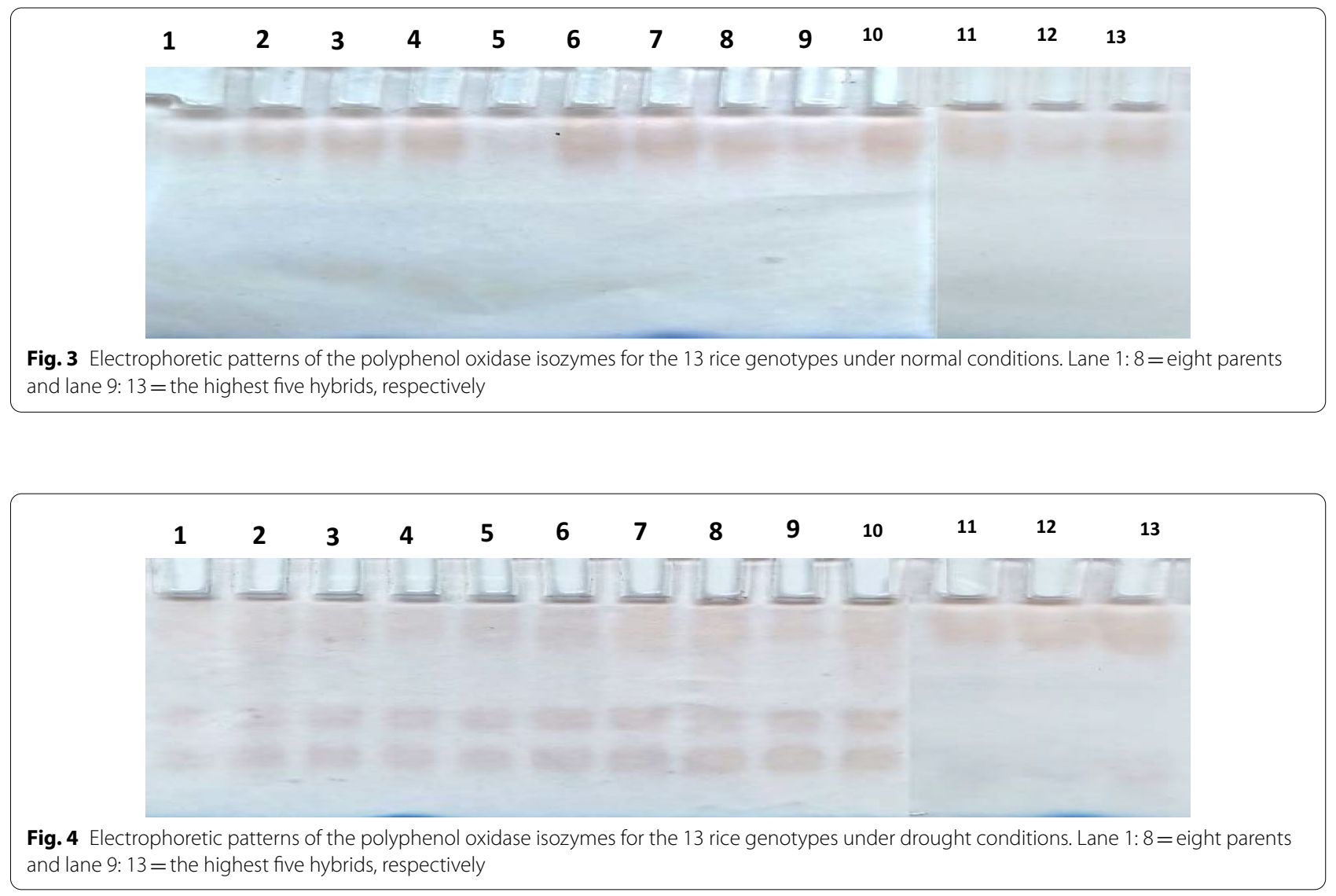


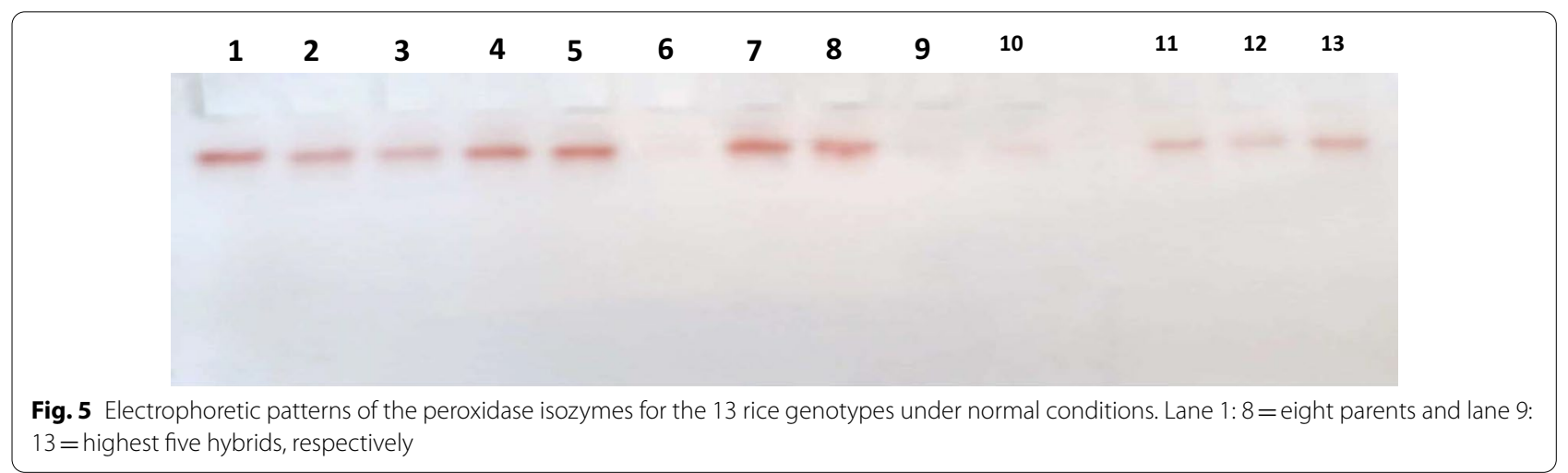

\begin{tabular}{|l|l|l|l|l|l|lllllll}
\hline $\mathbf{1}$ & $\mathbf{2}$ & $\mathbf{3}$ & $\mathbf{4}$ & $\mathbf{5}$ & $\mathbf{6}$ & $\mathbf{7}$ & $\mathbf{8}$ & $\mathbf{9}$ & $\mathbf{1 0}$ & $\mathbf{1 1}$ & $\mathbf{1 2}$ \\
\hline
\end{tabular}

was observed that this analysis contributed in some detail to clarifying the importance of additive gene action and its interactions which are responsible for water stress tolerance in rice. Hence, the five superior F1 crosses of rice for drought tolerance were the nucleus on which the simple selection program will be built after each segregation generation to reach rice lines with highly genetic stability and yield as well as resistance to biotic and abiotic stresses (El-Mouhamady 2003; El-Keredy et al. 2003a, b, c A; El-Mouhamady 2009; El-Mouhamady et al. 2011; Farid et al. 2016; Ramadan et al. 2016; Esmail et al. 2016; ElMouhamady et al. 2016; Khatab et al. 2017; El- Demardash et al. 2017; El-Sayed et al. 2018; El-Mouhamady et al. 2019; Mwando et al. 2020; El-Mouhamady and Ibrahim 2020). Results viewed in Table 3 are related to mean performance of all studied traits under both experiments which may reflect the ability of water stress tolerance in rice using many mechanisms. Among these physiological mechanisms, the depth root system comes at the first. Because the depth root system during water stress helps the plant to reach the water stored in the far layers in soil, this mechanism enables it to preserve his life by doing a reasonable limit of biological, biochemical and physiological processes and in the end gives a good yield under this environmental pressure. In addition, the significant increase in the other root traits mentioned above also succeeded in making an integrated episode of drought tolerance mechanism in rice. In the same context, it was observed that osmotic adjustment trait was also of great importance in reducing the losing rate of the amount of transpiration water during the various metabolism processes and protecting plant cells from the phase of bilium. This is a new addition in the genetic improvement in rice to counter water-deficit conditions (El-Keredy et al. 2003a, b, c B; Abdel Sattar and El-Mouhamady 2012; Zian et al. 2013; El-Mouhamady et al. 2014a, b, 2021a; Heiba et al. 2016a, b; Yang et al. 2019; Al-Kordy et al. 2019; Sadiya 2020; Khatab et al. 2021).

In the same vein, it can be said that the yield and root attributes besides osmotic adjustment modified were the most important field measurements of interest and appreciation. On that basis, it gave a complete and clear picture of the effect of water stress on the various genotypes of rice crop. This, of course, is to draw a trend that shows the nature of drought-tolerant trait in rice, depending on the results of these field measurements. Results obtained showed that the genotypes of the aforementioned superior parents and their hybrids had already succeeded in 
Table 2 ANOVA test for all studied traits of rice accessions for both experiments of normal and drought stress conditions

\begin{tabular}{|c|c|c|c|c|c|c|c|c|c|c|c|c|c|c|c|}
\hline \multirow[t]{2}{*}{ SOV } & \multirow[t]{2}{*}{ DF } & \multicolumn{2}{|c|}{ Heading date (days) } & \multicolumn{2}{|c|}{ Plant height (cm) } & \multicolumn{4}{|c|}{$\begin{array}{l}\text { Number of filled } \\
\text { grains/panicle }\end{array}$} & \multicolumn{4}{|c|}{ 1000-grain weight (g) } & \multicolumn{2}{|c|}{$\begin{array}{l}\text { Grain yield/plant } \\
\text { (g) }\end{array}$} \\
\hline & & $\mathrm{N}$ & $\mathrm{S}$ & $\mathrm{N}$ & $S$ & \multicolumn{2}{|l|}{ N } & \multicolumn{2}{|l|}{$S$} & \multicolumn{2}{|l|}{$\mathbf{N}$} & \multicolumn{2}{|l|}{$S$} & $\mathrm{~N}$ & $\mathrm{~S}$ \\
\hline Rep & 2 & 3.18 & 4.22 & 11.14 & 8.37 & \multicolumn{2}{|c|}{1.78} & \multicolumn{2}{|c|}{2.66} & \multicolumn{2}{|c|}{12.05} & \multicolumn{2}{|c|}{5.04} & 9.88 & 7.12 \\
\hline Genotypes & 22 & $49.37^{* *}$ & $38.05^{* *}$ & $79.64^{* *}$ & $91.03^{* *}$ & \multicolumn{2}{|c|}{$19.58^{* *}$} & \multicolumn{2}{|c|}{$24.30^{* *}$} & \multicolumn{2}{|c|}{$57.23^{* *}$} & \multicolumn{2}{|c|}{$61.03^{* *}$} & $44.57^{* *}$ & $31.07^{* *}$ \\
\hline Parents & 7 & $113.52^{* *}$ & $110.75^{* *}$ & $82.55^{* *}$ & $77.18^{* *}$ & \multicolumn{2}{|c|}{$164.73^{* *}$} & \multicolumn{2}{|c|}{$95.73^{* *}$} & \multicolumn{2}{|c|}{$22.53^{* *}$} & \multicolumn{2}{|c|}{$18.61^{* *}$} & $17.25^{* *}$ & $13.02^{* *}$ \\
\hline Crosses & 14 & $190.13^{* *}$ & $243.0^{* *}$ & $140.02^{* *}$ & $162.58^{* *}$ & \multicolumn{2}{|c|}{$180.36^{* *}$} & \multicolumn{2}{|c|}{$126.94^{* *}$} & \multicolumn{2}{|c|}{$38.17^{* *}$} & \multicolumn{2}{|c|}{$26.15^{* *}$} & $68.05^{* *}$ & $47.13^{* *}$ \\
\hline P vs. C & 1 & $12.74^{* *}$ & $8.34^{* *}$ & $32.11^{* *}$ & $56.14^{* *}$ & 100 & $28^{* *}$ & 105 & $3^{* *}$ & & $4^{* *}$ & & $5^{* *}$ & $29.80^{* *}$ & $37.26^{* *}$ \\
\hline Lines $(\mathrm{L})$ & 4 & $123.59^{* *}$ & $146.68^{* *}$ & $29.18^{* *}$ & $37.05^{* *}$ & & $26^{* *}$ & & $5^{* *}$ & 115 & $9^{* *}$ & 148 & $1^{* *}$ & $94.28^{* *}$ & $139.22^{* *}$ \\
\hline Testers $(T)$ & 2 & $345.11^{* *}$ & $389.35^{* *}$ & $110.27^{* *}$ & $123.05^{* *}$ & 183 & $50^{* *}$ & 161 & $3^{* *}$ & 174 & $3^{* *}$ & 146 & $8^{* *}$ & $79.46^{* *}$ & $58.23^{* *}$ \\
\hline$L x T$ & 8 & $255.23^{* *}$ & $374.05^{* *}$ & $174.02^{* *}$ & $193.66^{* *}$ & & $94^{* *}$ & & $20^{* *}$ & 103 & $8^{* *}$ & & $6^{* *}$ & $81.16^{* *}$ & $104.29^{* *}$ \\
\hline Error & 44 & 6.05 & 5.40 & 2.83 & 1.59 & & 36 & & & & & & & 1.68 & 1.42 \\
\hline SOV & DF & $\begin{array}{l}\text { Maximur } \\
(\mathrm{cm})\end{array}$ & oot length & Number & of roots/pl & & Root & volut & & & $\begin{array}{l}\text { Root } \\
\text { num }\end{array}$ & $=1$ & vessel & & $\begin{array}{l}\text { Osmotic } \\
\text { adjustment }\end{array}$ \\
\hline & & $N$ & $S$ & $\mathrm{~N}$ & $S$ & & $\mathrm{~N}$ & & $S$ & & $\mathrm{~N}$ & & $S$ & & \\
\hline Rep & 2 & 23.04 & 15.66 & 10.07 & 4.35 & & 6.7 & & & & 2.9 & & 1.8 & & 0.78 \\
\hline Genotypes & 22 & $54.67^{* *}$ & $103.02^{* *}$ & $26.14^{* *}$ & $36.0^{* *}$ & & 72.6 & & & $3^{* *}$ & 41.0 & & 29.7 & $75^{* *}$ & $39.74^{* *}$ \\
\hline Parents & 7 & $224.54^{* *}$ & $178.15^{* *}$ & $140.07^{* *}$ & 119.33 & & 28.3 & & & & 68.4 & & $47.1 \varepsilon$ & $8^{* *}$ & $83.21^{* *}$ \\
\hline Crosses & 14 & $388.25^{* *}$ & $310.06^{* *}$ & $220.18^{* *}$ & 310.37 & & 73.3 & & & & 125.4 & & 73.63 & $53^{* *}$ & $284.49^{* *}$ \\
\hline P vs. C & 1 & $114.35^{* *}$ & $84.77^{* *}$ & $157.24^{* *}$ & 128.33 & & 13.9 & & & & 48.1 & & 72.65 & $59^{* *}$ & $15.09^{* *}$ \\
\hline Lines (L) & 4 & $509.23^{* *}$ & $370.45^{* *}$ & $84.27^{* *}$ & $69.0^{* *}$ & & 19.4 & & & $0^{* *}$ & 283.7 & & 190.3 & $34^{* *}$ & $117.31^{* *}$ \\
\hline Testers $(T)$ & 2 & $142.41^{* *}$ & $112.36^{* *}$ & $189.28^{* *}$ & 173.11 & & 259.2 & & 236 & & 57.1 & & 70.0 & $4^{* *}$ & $182.64^{* *}$ \\
\hline$L x T$ & 8 & $26.81^{* *}$ & $19.44^{* *}$ & $14.55^{* *}$ & 11.09 & & 69.1 & & & & 18.4 & & 22.30 & $30^{* *}$ & $65.04^{* *}$ \\
\hline Error & 44 & 7.16 & 5.12 & 1.08 & 1.13 & & 1.2 & & & & 2.7 & & 3.11 & 1 & 0.03 \\
\hline
\end{tabular}

$\mathrm{N}$ : normal and S: stress

giving a good level in relation to the final output and its various components. Also, it showed a great superiority for the characters of the root system, which had a fundamental role in preserving the life of plants during a state of water stress. Also, developing a state of resistance to water stress through a high degree of genetic improvement was translated through genetic evolution in changing the high osmotic pressure and reducing it to safe limits suitable for physiological and biochemical processes with successful and safe form. This matter enabled the plant to continue in its life and give a good crop under drought conditions compared to the standard experiment. In the end, it can be said that this evaluation was a successful and fruitful one as well for sorting and sifting a large number of parents and their hybrids besides determining their function on the problem of limited water needed for irrigation (El-Keredy et al. 2003a, b, c; El-Mouhamady 2009; Eldessouky et al. 2016; Abo-Hamid 2016; El-Mouhamady and Habouh 2019). Results detected in Table 4 indicated the importance of dominance gene action and the interactions besides the fruitful role of SCA effects for controlling all attributes evaluated for water stress bearing in rice genotypes. This fact would reflect the success achieved in the genetic amelioration of drought tolerance in the previous superior rice accessions. Also, continuing to cultivate these promising rice genotypes for a few segregation generations may eventually lead to obtaining rice lines classified as high genetic stability and high water-deficit tolerance besides high output. This also shows that the hybrid vigor or its improved image according to the direction of each trait whether in the positive or negative direction was strong evidence for the genetic improvement to drought tolerance in this context. In addition, it indicated in a large and clear manner that these genotypes are the main nucleus for the production water stress rice varieties in the coming years. This is considered a major advance in facing the unfavorable environmental conditions by traditional plant breeding methods. Moreover, it was found that the noticeable superiority in all results obtained of rice hybrids over both parents, especially the supreme parent in most of all attributes under evaluating, is attributed to the transgressive segregation. This fact confirms that most of these traits coalesced and together created an integral circle to achieve a drought tolerance trait in rice. This also confirms that water stress tolerance trait is considering a 
Table 3 Mean performance of all rice accessions for all studied traits for the two experiments of normal and drought stress conditions

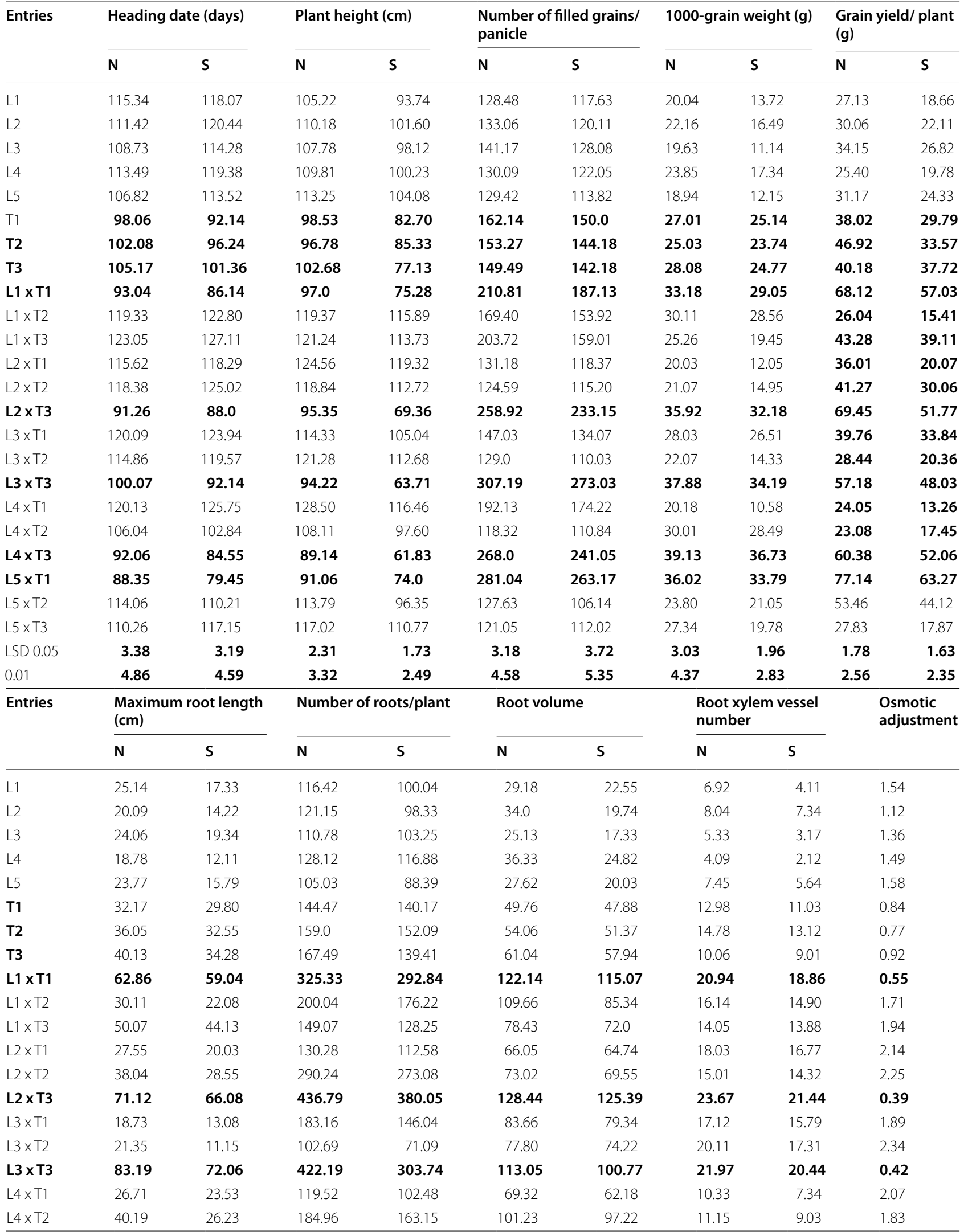


Table 3 (continued)

\begin{tabular}{|c|c|c|c|c|c|c|c|c|c|}
\hline \multirow[t]{2}{*}{ Entries } & \multicolumn{2}{|c|}{$\begin{array}{l}\text { Maximum root length } \\
(\mathrm{cm})\end{array}$} & \multicolumn{2}{|c|}{ Number of roots/plant } & \multicolumn{2}{|c|}{ Root volume } & \multicolumn{2}{|c|}{$\begin{array}{l}\text { Root xylem vessel } \\
\text { number }\end{array}$} & \multirow[t]{2}{*}{$\begin{array}{l}\text { Osmotic } \\
\text { adjustment }\end{array}$} \\
\hline & $\mathbf{N}$ & $S$ & $\mathbf{N}$ & $\mathrm{S}$ & $\mathrm{N}$ & $S$ & $\mathbf{N}$ & $S$ & \\
\hline L4 x T3 & 55.13 & 52.60 & 368.55 & 347.11 & 131.06 & 129.14 & 27.13 & 24.57 & 0.29 \\
\hline $\mathrm{L} 5 \times \mathrm{T} 1$ & 69.80 & 64.32 & 501.39 & 477.92 & 116.02 & 112.44 & 25.03 & 23.12 & 0.61 \\
\hline $\mathrm{L} 5 \times \mathrm{T} 2$ & 33.04 & 22.76 & 153.17 & 137.01 & 65.03 & 61.14 & 16.83 & 13.91 & 1.85 \\
\hline $\mathrm{L} 5 \times \mathrm{T} 3$ & 20.44 & 12.88 & 100.02 & 64.79 & 91.08 & 80.13 & 10.93 & 7.43 & 2.01 \\
\hline LSD 0.05 & 3.67 & 3.11 & 1.42 & 1.46 & 1.54 & 1.59 & 2.29 & 2.42 & 0.23 \\
\hline 0.01 & 5.29 & 4.47 & 2.05 & 2.01 & 2.22 & 2.29 & 3.30 & 3.48 & 0.34 \\
\hline
\end{tabular}

quantitative trait and was affected by all the previously studied traits. This is the desired goal of the breeder in the breeding program to water-deficit tolerance in rice crop (El-Keredy et al. 2003a, b, c; El-Mouhamady et al. 2010, 2015; El-Mouhamady et al. 2012a, b, c; El-Mouhamady et al. 2012a, b, c; El-Mouhamady et al. 2012a, b, c; Eldessouky et al. 2016; Khatab et al. 2019). Data showed in Table 5 revealed that additive and additive $\mathrm{X}$ additive types of genetic variance were functioned a profitable turn for controlling and inheriting the previous traits under studying for the two experiments for enhancing water stress tolerance in rice plants and increasing the importance of GCA effects in this regard. Results observed in Table 6 indicated the magnitude of dominance variance, the interactions and the impacted function of SCA effects for inheriting all attributes evaluated beneath desiccation bearing in rice genotypes. In addition, the importance of this parameter is heterosis over better parent. This is clear evidence for the successful achievement of the genetic improvement to drought tolerance in rice. This will continue to cultivate and track those five promising hybrids for water stress tolerance in the coming segregation generations to reach the complete genetic stability to produce new rice lines that are tolerant of water-deficit stress. Also, producing high output indicates the fruitful role of additive, dominance gene actions and their interactions in plant breeding. Accordingly, the analysis combining ability effects had the greatest impact in determining how to deal with the genotypes under studying and to determine which ones are compatible with the other and which ones are incompatible. This will also help the plant breeder to better choose the parents involved in the design of the hybrid program in the following studies. This will, of course, lead to a desirable scientific complement to the genetic improvement in tolerance to salinity, toxicity of heavy elements, diseases and other environmental and biological challenges based on the desired results of tolerance and resistance for water stress in those genotypes in this context (Abo-Hamid et al. 2016; Tawfik and El-Mouhamady 2019; El-Mouhamady and El-Metwally 2020). After all results of the current study, especially the results of line $\mathrm{X}$ tester analysis, it was noted that all the measurements taken during the genetic analysis of all tested attributes under both conditions proved that the superior genetic accessions, whether from parents or hybrids, had the lead in achieving the desired goal. It is simply extraction rice genotypes enduring to water stress in order to be a high yielding Egyptian lines, in addition to resistant to unfavorable environmental conditions in the coming years. These genotypes have already succeeded during all studied genetic parameters in achieving positive results in the final yield obtained under water stress conditions compared to the normal conditions. Generally, it is well known that protein patterns are used as a good guide for plants under stress conditions (Radotic et al. 2000; El-Beltagi et al. 2010; El-Seidy et al. 2013; El-Mouhamady et al. 2014a, b; Kishk et al. 2017; ElMouhamady et al. 2021a, b a \& b). The presence of some bands under drought stress conditions and their absence from the control genotypes (Tables 7 and 8 and Figs. 1 and 2) could be referring to the activation of some genes related to drought stress conditions. This stimulation of gene expression is due to the low content of conservative genes present in the plant genus. These results are consistent with El-Mouhamady et al. (2020) and Yang et al. (2006) who found that gene expression pattern is changed upon exposure to high temperature. Our consequences are similar to Shafina et al. (2015) who analyzed 24 rice genotypes under drought stress conditions for proteins profile and Reshma et al. (2020) who studied the changes in leaf protein pattern of 12 maize genotypes under drought stress conditions. Figures 1 and 2 show that proteins located at the bottom of the gel are more intensified than those located at the above of the gel. This observation is in agreement with Najaphy et al. (2014). Najaphy et al. (2010) reported that drought stress conditions increase intensification of soluble proteins in chickpea leaves up to $43 \%$ in comparison with the standard 
Table 4 Estimates of heterosis over better parent in 15 rice hybrids for all studied traits in both experiments of normal and drought stress conditions

\begin{tabular}{|c|c|c|c|c|c|c|c|c|c|c|}
\hline \multirow[t]{2}{*}{ Entries } & \multicolumn{2}{|c|}{ Heading date (days) } & \multicolumn{2}{|c|}{ Plant height (cm) } & \multicolumn{2}{|c|}{$\begin{array}{l}\text { Number of filled } \\
\text { grains/panicle }\end{array}$} & \multicolumn{2}{|c|}{ 1000-grain weight (g) } & \multicolumn{2}{|c|}{ Grain yield/plant (g) } \\
\hline & $\mathbf{N}$ & s & $\mathrm{N}$ & S & $\mathbf{N}$ & $\mathrm{S}$ & $\mathbf{N}$ & $S$ & $\mathrm{~N}$ & $\mathrm{~S}$ \\
\hline $\mathrm{L} 1 \times \mathrm{T} 1$ & $-5.11^{* *}$ & $-6.51 * *$ & -1.85 NS & $-8.97^{* *}$ & $30.01^{* *}$ & $24.75^{* *}$ & $22.84^{* *}$ & $15.55^{* *}$ & $79.16^{* *}$ & $91.44^{* *}$ \\
\hline $\mathrm{L} 1 \times \mathrm{T} 2$ & $21.69 * *$ & $33.27^{* *}$ & $23.34^{* *}$ & $35.81^{* *}$ & $10.52^{* *}$ & $6.75^{* *}$ & $20.29 * *$ & $20.30^{* *}$ & $-44.50^{* *}$ & $-54.09 * *$ \\
\hline $\mathrm{L} 1 \times \mathrm{T} 3$ & $17.0^{* *}$ & $25.40^{* *}$ & $18.07^{* *}$ & $47.45^{* *}$ & $36.27^{* *}$ & $11.83^{* *}$ & -10.04 NS & $-21.47^{* *}$ & $7.71^{* *}$ & $3.68 \mathrm{NS}$ \\
\hline $\mathrm{L} 2 \times \mathrm{T} 1$ & $17.90^{* *}$ & $22.91^{* *}$ & $26.41^{* *}$ & $44.28 * *$ & $-19.09^{* *}$ & $-21.08^{* *}$ & $-25.84^{* *}$ & $-52.06^{* *}$ & $-5.28^{*}$ & $-32.62^{* *}$ \\
\hline $\mathrm{L} 2 \times \mathrm{T} 2$ & $15.96^{* *}$ & $29.90^{* *}$ & $22.79^{* *}$ & $32.09^{* *}$ & $-18.71^{* *}$ & $-20.09^{* *}$ & $-15.82^{*}$ & $-37.02^{* *}$ & $-12.04^{* *}$ & $-10.45^{* *}$ \\
\hline $\mathrm{L} 2 \times \mathrm{T} 3$ & $-13.22^{* *}$ & $-13.18^{* *}$ & $-7.13^{* *}$ & $-10.07^{* *}$ & $73.20^{* *}$ & $63.98^{* *}$ & $27.92^{* *}$ & $29.91 * *$ & $72.84^{* *}$ & $37.24^{* *}$ \\
\hline $\mathrm{L} 3 \times \mathrm{T} 1$ & $22.46^{* *}$ & $34.51^{* *}$ & $16.03^{* *}$ & $27.01^{* *}$ & $-9.31^{* *}$ & $-10.62^{* *}$ & 3.77 NS & $5.44 \mathrm{NS}$ & 4.57 NS & $13.59^{* *}$ \\
\hline $\mathrm{L} 3 \times \mathrm{T} 2$ & $12.51^{* *}$ & $24.24^{* *}$ & $25.31^{* *}$ & $32.05^{* *}$ & $-15.83^{* *}$ & $-23.68^{* *}$ & -11.82 NS & $-39.63^{* *}$ & $-39.38^{* *}$ & $-39.35^{* *}$ \\
\hline $\mathrm{L} 3 \times \mathrm{T} 3$ & $-4.84^{* *}$ & $-9.09 * *$ & $-8.23^{* *}$ & $-17.39 * *$ & $105.49^{* *}$ & $92.03^{* *}$ & $34.90^{* *}$ & $38.02^{* *}$ & $42.30^{* *}$ & $27.33^{* *}$ \\
\hline $\mathrm{L} 4 \times \mathrm{T} 1$ & $22.50^{* *}$ & $36.47^{* *}$ & $30.41^{* *}$ & $40.82^{* *}$ & $18.49^{* *}$ & $16.14^{* *}$ & $-25.28^{* *}$ & $-57.91^{* *}$ & $-36.74^{* *}$ & $-55.48^{* *}$ \\
\hline $\mathrm{L} 4 \times \mathrm{T} 2$ & $3.87 *$ & $6.85^{* *}$ & $11.70^{* *}$ & $14.37^{* *}$ & $-22.80^{* *}$ & $-23.12^{* *}$ & $19.89 * *$ & $20.0^{* *}$ & $-50.80^{* *}$ & $-48.01^{* *}$ \\
\hline $\mathrm{L} 4 \times \mathrm{T} 3$ & $-12.46^{* *}$ & $-16.58^{* *}$ & $-13.18^{* *}$ & $-19.83^{* *}$ & $79.27^{* *}$ & $69.53^{* *}$ & $39.35^{* *}$ & $48.28^{* *}$ & $50.27^{* *}$ & $74.75^{* *}$ \\
\hline $\mathrm{L} 5 \times \mathrm{T} 1$ & $-9.90^{* *}$ & $-13.77^{* *}$ & $-7.58^{* *}$ & $-10.51^{* *}$ & $73.33^{* *}$ & $75.44^{* *}$ & $28.27^{* *}$ & $36.41^{* *}$ & $102.89^{* *}$ & $112.38^{* *}$ \\
\hline $\mathrm{L} 5 \times \mathrm{T} 2$ & $11.73^{* *}$ & $14.51^{* *}$ & $17.57^{* *}$ & $12.91^{* *}$ & $-16.72^{* *}$ & $-26.38^{* *}$ & $-4.91 \mathrm{NS}$ & $-11.33^{*}$ & $13.93^{* *}$ & $31.42^{* *}$ \\
\hline L5 XT3 & $4.83^{* *}$ & $15.57^{* *}$ & $13.96^{* *}$ & $43.61^{* *}$ & $-19.02^{* *}$ & $-21.21^{* *}$ & $-2.63 \mathrm{NS}$ & $-20.14^{* *}$ & $-30.73^{* *}$ & $-52.62^{* *}$ \\
\hline LSD 0.05 & 3.38 & 3.19 & 2.31 & 1.73 & 3.18 & 3.72 & 3.03 & 1.96 & 1.78 & 1.63 \\
\hline 0.01 & 4.86 & 4.59 & 3.32 & 2.49 & 4.58 & 5.35 & 4.37 & 2.83 & 2.56 & 2.35 \\
\hline \multirow[t]{2}{*}{ Crosses } & \multicolumn{2}{|c|}{$\begin{array}{l}\text { Maximum root length } \\
(\mathrm{cm})\end{array}$} & \multicolumn{2}{|c|}{ Number of roots/plant } & \multicolumn{2}{|c|}{ Root volume } & \multicolumn{2}{|c|}{$\begin{array}{l}\text { Root xylem vessel } \\
\text { number }\end{array}$} & \multirow{2}{*}{\multicolumn{2}{|c|}{ Osmotic adjustment }} \\
\hline & $\mathbf{N}$ & $\mathrm{s}$ & $\mathbf{N}$ & $\mathrm{S}$ & $\mathbf{N}$ & $S$ & $\mathrm{~N}$ & S & & \\
\hline L1 x T1 & $95.39 * *$ & $98.12^{* *}$ & $125.18^{* *}$ & $108.91^{* *}$ & $145.45^{* *}$ & $140.32^{* *}$ & $61.32^{* *}$ & $69.17^{* *}$ & \multicolumn{2}{|l|}{$-34.52^{*}$} \\
\hline $\mathrm{L} 1 \times \mathrm{T} 2$ & $-16.47^{* *}$ & $-32.16^{* *}$ & $25.81^{* *}$ & $15.86^{* *}$ & $102.84^{* *}$ & $66.12^{* *}$ & $9.20 \mathrm{NS}$ & $13.56 \mathrm{NS}$ & \multicolumn{2}{|l|}{$122.07^{* *}$} \\
\hline $\mathrm{L} 1 \times \mathrm{T} 3$ & $24.76^{* *}$ & $28.73^{* *}$ & $-10.99^{* *}$ & $-8.0^{* *}$ & $28.48^{* *}$ & $24.26^{* *}$ & $39.66^{* *}$ & $54.05^{* *}$ & \multicolumn{2}{|l|}{$110.86^{* *}$} \\
\hline $\mathrm{L} 2 \times \mathrm{T} 1$ & $-14.36^{*}$ & $-32.78^{* *}$ & $-9.82^{* *}$ & $-19.68^{* *}$ & $32.73 * *$ & $35.21 * *$ & $38.90^{* *}$ & $52.03^{* *}$ & \multicolumn{2}{|l|}{$154.76^{* *}$} \\
\hline $\mathrm{L} 2 \times \mathrm{T} 2$ & $5.52 \mathrm{NS}$ & $-12.28^{*}$ & $82.54^{* *}$ & $79.55^{* *}$ & $35.07^{* *}$ & $35.39 * *$ & $1.55 \mathrm{NS}$ & 9.14 NS & \multicolumn{2}{|l|}{$192.20^{* *}$} \\
\hline L2 $\times$ T3 & $77.22^{* *}$ & $92.76^{* *}$ & $160.78 * *$ & $172.61^{* *}$ & $110.41^{* *}$ & $116.41^{* *}$ & $135.28^{* *}$ & $137.95^{* *}$ & \multicolumn{2}{|l|}{$-57.60^{* *}$} \\
\hline $\mathrm{L} 3 \times \mathrm{T} 1$ & $-41.77^{* *}$ & $-56.10^{* *}$ & $26.78 * *$ & $4.18^{* *}$ & $68.12^{* *}$ & $65.70^{* *}$ & $31.89 * *$ & $43.15 * *$ & \multicolumn{2}{|l|}{$125.0^{* *}$} \\
\hline $\mathrm{L} 3 \times \mathrm{T} 2$ & $-40.77^{* *}$ & $-65.74^{* *}$ & $-35.41^{* *}$ & $-53.25^{* *}$ & $43.91 * *$ & $44.48^{* *}$ & $36.06^{* *}$ & $31.93 * *$ & \multicolumn{2}{|l|}{$203.89^{* *}$} \\
\hline L3 x T3 & $107.30^{* *}$ & $110.21^{* *}$ & $152.06^{* *}$ & $117.87^{* *}$ & $85.20 * *$ & $73.92^{* *}$ & $118.38^{* *}$ & $126.85^{* *}$ & \multicolumn{2}{|l|}{$-54.34^{* *}$} \\
\hline $\mathrm{L} 4 \times \mathrm{XT1}$ & $-16.97^{* *}$ & $-21.04^{* *}$ & $-17.27^{* *}$ & $-26.88^{* *}$ & $39.30^{* *}$ & $29.86^{* *}$ & $-20.41 *$ & $-33.45^{* *}$ & \multicolumn{2}{|l|}{$146.42^{* *}$} \\
\hline $\mathrm{L} 4 \times \mathrm{T} 2$ & $11.48^{*}$ & $-19.41^{* *}$ & $16.32^{* *}$ & $7.27^{* *}$ & $87.25^{* *}$ & $89.25^{* *}$ & $-24.56^{* *}$ & $-31.17^{* *}$ & \multicolumn{2}{|l|}{$137.66^{* *}$} \\
\hline L4 x T3 & $37.37^{* *}$ & $53.44^{* *}$ & $120.04 * *$ & $148.98^{* *}$ & $114.71^{* *}$ & $122.88^{* *}$ & $169.68^{* *}$ & $172.69^{* *}$ & \multicolumn{2}{|l|}{$-68.47^{* *}$} \\
\hline L5 x T1 & $116.97^{* *}$ & $115.83^{* *}$ & $247.05^{* *}$ & $240.95^{* *}$ & $133.15^{* *}$ & $134.83^{* *}$ & $92.83^{* *}$ & $109.61 * *$ & \multicolumn{2}{|l|}{$-27.38^{*}$} \\
\hline $\mathrm{L} 5 \times \mathrm{T} 2$ & -8.34 NS & $-30.07^{* *}$ & $-3.66^{* *}$ & $-9.91^{* *}$ & $20.29 * *$ & $19.01^{* *}$ & 13.87 NS & 6.02 NS & $140.25^{* *}$ & \\
\hline $\mathrm{L} 5 \times \mathrm{T} 3$ & $-49.06^{* *}$ & $-62.42^{* *}$ & $-40.28^{* *}$ & $-53.52^{* *}$ & $49.21 * *$ & $38.29 * *$ & 8.64 NS & -17.53 NS & $118.47^{* *}$ & \\
\hline LSD 0.05 & 3.67 & 3.11 & 1.42 & 1.46 & 1.54 & 1.59 & 2.29 & 2.42 & 0.23 & \\
\hline 0.01 & 5.29 & 4.47 & 2.05 & 2.01 & 2.22 & 2.29 & 3.30 & 3.48 & 0.34 & \\
\hline
\end{tabular}

treatment, but did not significantly affect electrophoretic protein pattern profiles. Drought stress conditions decrease the solubility of high molecular weight proteins and increase the solubility of low molecular weight proteins (Farshadfar et al. 2008; Moradpour et al. 2014). As a general adaptation strategy, plants enhance the activities of antioxidant enzyme to overcomeoxidative stress conditions (Foyer and Noctor 2003). The present study showed elevated activities of PPO, GST and POD under drought stress conditions in comparison with the normal ones. Drought-induced dehydration leads to accumulation of specialized metabolites that are able to induce water retention and enhance the generation of ROS (Verslues and Juenger 2011; Nakabayashi and Saito 2015; 
Table 5 Evaluated of GCA effects in eight rice parents of all studied traits for the two experiments of normal and drought stress conditions

\begin{tabular}{|c|c|c|c|c|c|c|c|c|c|c|}
\hline \multirow[t]{2}{*}{ Parents } & \multicolumn{2}{|c|}{ Heading date (days) } & \multicolumn{2}{|c|}{ Plant height (cm) } & \multicolumn{2}{|c|}{$\begin{array}{l}\text { Number of filled grains/ } \\
\text { panicle }\end{array}$} & \multicolumn{2}{|c|}{$1000-$ grain weight $(g)$} & \multicolumn{2}{|c|}{ Grain yield/plant (g) } \\
\hline & $\mathbf{N}$ & $S$ & $\mathbf{N}$ & $S$ & $\mathbf{N}$ & $\mathrm{S}$ & $\mathbf{N}$ & $\mathrm{S}$ & $\mathrm{N}$ & $S$ \\
\hline \multicolumn{11}{|l|}{ Lines } \\
\hline $\mathrm{L}_{1}$ & $4.89^{* *}$ & $13.78^{* *}$ & $2.77^{* *}$ & $6.82^{* *}$ & $-9.37^{* *}$ & $-3.80^{* *}$ & $-7.36^{* *}$ & $-5.18^{* *}$ & $-14.71^{* *}$ & $-1.54^{* *}$ \\
\hline $\mathrm{L}_{2}$ & $36.80^{* *}$ & $20.26^{* *}$ & $8.84^{* *}$ & $14.38^{* *}$ & $-12.70^{* *}$ & $-6.28^{* *}$ & $-29.38^{* *}$ & $-21.04^{* *}$ & $-2.42^{* *}$ & $-4.67^{* *}$ \\
\hline $\mathrm{L}_{3}$ & $-54.22^{* *}$ & $-69.27^{* *}$ & $-17.60^{* *}$ & $-28.18^{* *}$ & $58.59^{* *}$ & $36.44^{* *}$ & $61.22^{* *}$ & $37.96^{* *}$ & $33.28^{* *}$ & $44.87^{* *}$ \\
\hline $\mathrm{L}_{4}$ & $2.46^{* *}$ & $13.09^{* *}$ & $3.60^{* *}$ & $2.91^{* *}$ & $-31.08^{* *}$ & $-19.18^{* *}$ & $-14.45^{* *}$ & $-7.04^{* *}$ & $-9.12^{* *}$ & $-15.62^{* *}$ \\
\hline$L_{5}$ & $10.07^{* *}$ & $22.14^{* *}$ & $2.39^{* *}$ & $4.07^{* *}$ & $-5.44^{* *}$ & $-7.18^{* *}$ & $-10.03^{* *}$ & $-4.70^{* *}$ & $-7.03^{* *}$ & $-23.04^{* *}$ \\
\hline LSD 0.05 & 1.39 & 1.27 & 1.68 & 1.52 & 3.48 & 2.78 & 4.28 & 3.91 & 1.09 & 1.03 \\
\hline 0.01 & 1.67 & 1.83 & 2.11 & 2.41 & 4.16 & 3.42 & 5.36 & 4.35 & 1.21 & 1.35 \\
\hline \multicolumn{11}{|l|}{ Testers } \\
\hline $\mathrm{T}_{1}$ & $-8.47^{* *}$ & $-14.0^{* *}$ & $-3.86^{* *}$ & $-5.02^{* *}$ & $17.32^{* *}$ & $24.05^{* *}$ & $6.19^{* *}$ & $10.13^{* *}$ & $4.85^{* *}$ & $6.02^{* *}$ \\
\hline $\mathrm{T}_{2}$ & $-23.07^{* *}$ & $-6.38^{* *}$ & $-9.06^{* *}$ & $-13.48^{* *}$ & $11.03^{* *}$ & $7.66^{* *}$ & $8.02^{* *}$ & $13.22^{* *}$ & $10.39^{* *}$ & $1.82^{* *}$ \\
\hline$T_{3}$ & $31.54^{* *}$ & $20.38^{* *}$ & $12.92^{* *}$ & $18.50^{* *}$ & $-28.35^{* *}$ & $-31.71^{* *}$ & $-14.21^{* *}$ & $-23.35^{* *}$ & $-15.24^{* *}$ & $-7.84^{* *}$ \\
\hline LSD 0.05 & 2.37 & 1.69 & 1.03 & 1.17 & 2.15 & 2.22 & 2.79 & 2.55 & 1.42 & 1.29 \\
\hline 0.01 & 2.79 & 2.03 & 1.42 & 1.83 & 2.77 & 3.04 & 3.14 & 3.21 & 1.87 & 1.74 \\
\hline \multirow[t]{2}{*}{ Parents } & \multicolumn{2}{|c|}{$\begin{array}{l}\text { Maximum root length } \\
(\mathrm{cm})\end{array}$} & \multicolumn{2}{|c|}{ Number of roots/plant } & \multicolumn{2}{|c|}{ Root volume } & \multicolumn{2}{|c|}{$\begin{array}{l}\text { Root xylem vessel } \\
\text { number }\end{array}$} & \multirow{2}{*}{\multicolumn{2}{|c|}{ Osmotic adjustment }} \\
\hline & $\mathrm{N}$ & $S$ & $\mathrm{~N}$ & $S$ & $\mathbf{N}$ & $\mathrm{S}$ & $\mathbf{N}$ & $S$ & & \\
\hline \multicolumn{11}{|l|}{ Lines } \\
\hline $\mathrm{L}_{1}$ & $-2.89^{* *}$ & $-1.94^{* *}$ & $-15.66^{* *}$ & $-9.56^{* *}$ & $-6.37^{* *}$ & $-4.17^{* *}$ & $-17.49^{* *}$ & $-12.58^{* *}$ & \multicolumn{2}{|l|}{$2.39^{* *}$} \\
\hline $\mathrm{L}_{2}$ & $-8.13^{* *}$ & $-3.11^{* *}$ & $-10.08^{* *}$ & $-24.05^{* *}$ & $-14.05^{* *}$ & $-10.23^{* *}$ & $-8.34^{* *}$ & $-10.09^{* *}$ & \multicolumn{2}{|l|}{$15.66^{* *}$} \\
\hline $\mathrm{L}_{3}$ & $19.84^{* *}$ & $16.83^{* *}$ & $38.22^{* *}$ & $52.11^{* *}$ & $53.28^{* *}$ & $28.64^{* *}$ & $33.84^{* *}$ & $34.97^{* *}$ & \multicolumn{2}{|l|}{$-30.81^{* *}$} \\
\hline $\mathrm{L}_{4}$ & $-5.67^{* *}$ & $-7.22^{* *}$ & $-7.88^{* *}$ & $-10.31^{* *}$ & $-22.70^{* *}$ & $-8.36^{* *}$ & $-2.78^{* *}$ & $-4.07^{* *}$ & \multicolumn{2}{|l|}{$3.19^{* *}$} \\
\hline$L_{5}$ & $-3.15^{* *}$ & $-4.56^{* *}$ & $-4.60^{* *}$ & $-8.19^{* *}$ & $-10.16^{* *}$ & $-5.88^{* *}$ & $-5.23^{* *}$ & $-8.23^{* *}$ & \multicolumn{2}{|l|}{$9.57^{* *}$} \\
\hline LSD 0.05 & 1.13 & 1.26 & 1.23 & 1.49 & 1.51 & 1.44 & 2.18 & 2.11 & \multicolumn{2}{|l|}{0.23} \\
\hline 0.01 & 1.62 & 1.89 & 1.73 & 1.83 & 1.73 & 2.02 & 2.31 & 2.53 & \multicolumn{2}{|l|}{0.46} \\
\hline \multicolumn{11}{|l|}{ Testers } \\
\hline $\mathrm{T}_{1}$ & $13.86^{* *}$ & $22.06^{* *}$ & $3.18^{* *}$ & $5.04^{* *}$ & $35.34^{* *}$ & $17.56^{* *}$ & $19.42^{* *}$ & $13.07^{* *}$ & \multicolumn{2}{|l|}{$-6.89^{* *}$} \\
\hline $\mathrm{T}_{2}$ & $16.04^{* *}$ & $7.18^{* *}$ & $6.24^{* *}$ & $11.89^{* *}$ & $26.86^{* *}$ & $14.08^{* *}$ & $3.57^{* *}$ & $6.25^{* *}$ & \multicolumn{2}{|l|}{$-11.05^{* *}$} \\
\hline $\mathrm{T}_{3}$ & $-29.90^{* *}$ & $-29.24^{* *}$ & $-9.42^{* *}$ & $-16.93^{* *}$ & $-62.20^{* *}$ & $-31.64^{* *}$ & $-22.99^{* *}$ & $-19.32^{* *}$ & \multicolumn{2}{|l|}{$17.94^{* *}$} \\
\hline LSD 0.05 & 1.02 & 0.93 & 1.78 & 1.53 & 1.36 & 1.25 & 1.16 & 0.86 & \multicolumn{2}{|l|}{0.51} \\
\hline 0.01 & 1.32 & 1.26 & 2.14 & 2.22 & 1.69 & 1.43 & 1.74 & 1.16 & \multicolumn{2}{|l|}{0.76} \\
\hline
\end{tabular}

Melandri et al. 2020). Our results are in consistent with that reported on Canola seedlings for POD and PPO enzyme activities (Ahmadi et al. 2015). Higher GST activity may be due to direct coupling between glutathione and protein to neutralize drought stress effect which is similar to the study reported by Reddy et al. (2005), El-Mouhamady et al. (2020) and El-Mouhamady et al. (2021a, b). GST overexpression leads to elevated accumulation of enzymatic and non-enzymatic components and plays an important role in repairing the effects of secondary oxidative stress generated during abiotic stresses (Roxas et al. 2000; Sharma et al. 2014; Rodziewicz et al. 2019). Other previous studies, as parallel with the present results, reported the increased POD activity under drought stress conditions in various plants, like liquorice (Pan et al. 2006), sunflower (Gunes et al. 2008), Brassica napus (Abedi and Pakniyat 2010), wheat (Weng et al. 2015) and barley (Hellal et al. 2020). All in all, the increase in POD activity is considered as a key point for the decomposition of $\mathrm{H}_{2} \mathrm{O}_{2}$, especially under catalase (CAT) inactivation (Abedi and Pakniyat 2010). CAT enzyme cannot be detected under our assay conditions as CAT has relatively weak coupling toward $\mathrm{H}_{2} \mathrm{O}_{2}$ with subsequent degradation in the presence of light which causes its photo-inactivation. Elevated accumulation of $\mathrm{H}_{2} \mathrm{O}_{2}$ causes CAT inactivation under severe drought and salinity stress conditions 
Table 6 Estimates of specific combining ability effects in the 15 rice hybrids for all characters evaluated under both normal and drought stress conditions

\begin{tabular}{|c|c|c|c|c|c|c|c|c|c|c|}
\hline \multirow[t]{2}{*}{ Crosses } & \multicolumn{2}{|c|}{ Heading date (days) } & \multicolumn{2}{|c|}{ Plant height $(\mathrm{cm})$} & \multicolumn{2}{|c|}{$\begin{array}{l}\text { Number of filled grains/ } \\
\text { panicle }\end{array}$} & \multicolumn{2}{|c|}{$1000-$ grain weight $(g)$} & \multicolumn{2}{|c|}{ Grain yield/plant (g) } \\
\hline & $\mathrm{N}$ & $S$ & $\mathrm{~N}$ & $S$ & $\mathrm{~N}$ & $\mathrm{~S}$ & $\mathrm{~N}$ & $\mathrm{~s}$ & $\mathrm{~N}$ & $\mathrm{~s}$ \\
\hline $\mathrm{L} 1 \times \mathrm{T} 1$ & $-42.79 * *$ & $-65.63^{* *}$ & $-122.15^{* *}$ & $-74.89^{* *}$ & $17.44^{* *}$ & $9.18^{* *}$ & $22.60^{* *}$ & $17.56^{* *}$ & $14.32^{* *}$ & $27.45^{* *}$ \\
\hline $\mathrm{L} 1 \times \mathrm{T} 2$ & $10.07^{* *}$ & $8.33^{* *}$ & $31.09^{* *}$ & $63.24^{* *}$ & $-5.87^{* *}$ & $-3.70^{* *}$ & $-11.05^{* *}$ & $-6.22^{* *}$ & $-6.15^{* *}$ & $-4.23^{* *}$ \\
\hline $\mathrm{L} 1 \times \mathrm{T} 3$ & $3.79^{* *}$ & $5.68^{* *}$ & $22.17^{* *}$ & $45.91^{* *}$ & $-10.48^{* *}$ & $-4.19^{* *}$ & $-8.24^{* *}$ & $-13.05^{* *}$ & $-2.77 * *$ & $-1.89 * *$ \\
\hline $\mathrm{L} 2 \times \mathrm{T} 1$ & $2.48^{* *}$ & $4.39^{* *}$ & $47.05^{* *}$ & $32.79^{* *}$ & $-22.76^{* *}$ & $-10.05^{* *}$ & $-10.13^{* *}$ & $-10.04^{* *}$ & $-4.80^{* *}$ & $-3.05^{* *}$ \\
\hline $\mathrm{L} 2 \times \mathrm{T} 2$ & $11.08^{* *}$ & $7.26^{* *}$ & $11.18^{* *}$ & $41.15^{* *}$ & $-3.89^{* *}$ & $-3.72^{* *}$ & $-14.70^{* *}$ & $-2.88^{* *}$ & $-9.03^{* *}$ & $-16.02^{* *}$ \\
\hline $\mathrm{L} 2 \times \mathrm{T} 3$ & $-59.07^{* *}$ & $-14.32^{* *}$ & $-48.22^{* *}$ & $-53.11^{* *}$ & $60.05^{* *}$ & $14.18^{* *}$ & $60.18^{* *}$ & $9.87^{* *}$ & $10.05^{* *}$ & $9.34 * *$ \\
\hline L3 $\times T 1$ & $26.52^{* *}$ & $14.08^{* *}$ & $9.12^{* *}$ & $16.03^{* *}$ & $-4.25^{* *}$ & $-4.08^{* *}$ & $-5.78^{* *}$ & $-7.34^{* *}$ & $-11.06^{* *}$ & $-2.63^{* *}$ \\
\hline L3 $\times$ T2 & $24.22^{* *}$ & $12.82^{* *}$ & $13.58^{* *}$ & $7.82^{* *}$ & $-15.90^{* *}$ & $-6.01^{* *}$ & $-13.20^{* *}$ & $-5.03^{* *}$ & $-4.78^{* *}$ & $-20.07^{* *}$ \\
\hline L3 $\times \mathrm{T} 3$ & $-27.52^{* *}$ & $-17.38^{* *}$ & $-82.54^{* *}$ & $-92.04^{* *}$ & $12.47^{* *}$ & $15.60^{* *}$ & $4.95^{* *}$ & $11.70^{* *}$ & $20.03^{* *}$ & $8.13^{* *}$ \\
\hline L4 XT1 & $9.33^{* *}$ & $13.62^{* *}$ & $45.28^{* *}$ & $13.48^{* *}$ & $-8.05^{* *}$ & $-5.0^{* *}$ & $-7.89^{* *}$ & $-2.67^{* *}$ & $-5.90^{* *}$ & $-2.94^{* *}$ \\
\hline $\mathrm{L} 4 \times \mathrm{T} 2$ & $19.68^{* *}$ & $23.02^{* *}$ & $76.38^{* *}$ & $22.17^{* *}$ & $-6.33^{* *}$ & $-11.37^{* *}$ & $-2.88^{* *}$ & $-4.11^{* *}$ & $-7.02^{* *}$ & $-1.81^{* *}$ \\
\hline $\mathrm{L} 4 \times \mathrm{T} 3$ & $-34.69^{* *}$ & $-28.48^{* *}$ & $-38.76^{* *}$ & $-102.53^{* *}$ & $10.03^{* *}$ & $5.04^{* *}$ & $7.83^{* *}$ & $25.04^{* *}$ & $35.67^{* *}$ & $46.84^{* *}$ \\
\hline $\mathrm{L} 5 \times \mathrm{T} 1$ & $-91.47^{* *}$ & $-55.42^{* *}$ & $-59.27^{* *}$ & $-88.14^{* *}$ & $7.33^{* *}$ & $23.17^{* *}$ & $5.43^{* *}$ & $3.67^{* *}$ & $13.07^{* *}$ & $16.55^{* *}$ \\
\hline $\mathrm{L} 5 \times \mathrm{T} 2$ & $36.88^{* *}$ & $20.04^{* *}$ & $10.04^{* *}$ & $39.12^{* *}$ & $-3.55^{* *}$ & $-4.79^{* *}$ & $-7.12^{* *}$ & $-3.45^{* *}$ & $-3.11^{* *}$ & $-37.40^{* *}$ \\
\hline $\mathrm{L} 5 \times \mathrm{T} 3$ & $111.49^{* *}$ & $71.99^{* *}$ & $85.05^{* *}$ & $129.0^{* *}$ & $-26.24^{* *}$ & $-14.26^{* *}$ & $-20.0^{* *}$ & $-13.05^{* *}$ & $-38.52^{* *}$ & $-18.27^{* *}$ \\
\hline LSD 0.05 & 1.46 & 1.36 & 2.83 & 2.59 & 2.84 & 2.65 & 1.76 & 1.55 & 1.38 & 1.26 \\
\hline 0.01 & 1.78 & 1.64 & 3.41 & 3.18 & 3.26 & 3.12 & 2.35 & 2.09 & 2.75 & 1.54 \\
\hline \multirow[t]{2}{*}{ Crosses } & \multicolumn{2}{|c|}{$\begin{array}{l}\text { Maximum root length } \\
(\mathrm{cm})\end{array}$} & \multicolumn{2}{|c|}{ Number of roots/plant } & \multicolumn{2}{|c|}{ Root volume } & \multicolumn{2}{|c|}{$\begin{array}{l}\text { Root xylem vessel } \\
\text { number }\end{array}$} & \multirow{2}{*}{\multicolumn{2}{|c|}{ Osmotic adjustment }} \\
\hline & $\mathrm{N}$ & S & $N$ & $\mathrm{~S}$ & $\mathrm{~N}$ & $S$ & $\mathbf{N}$ & $S$ & & \\
\hline $\mathrm{L} 1 \times \mathrm{T} 1$ & $35.78^{* *}$ & $29.32^{* *}$ & $12.85^{* *}$ & $54.02 * *$ & $12.57^{* *}$ & $16.78^{* *}$ & $13.85^{* *}$ & $12.05^{* *}$ & \multicolumn{2}{|c|}{$-15.38^{* *}$} \\
\hline $\mathrm{L} 1 \times \mathrm{T} 2$ & $-4.66^{* *}$ & $-7.58^{* *}$ & $-12.46^{* *}$ & $-16.04^{* *}$ & $-4.23^{* *}$ & $-1.93^{* *}$ & $-2.17^{* *}$ & $-5.14^{* *}$ & \multicolumn{2}{|c|}{$3.90^{* *}$} \\
\hline $\mathrm{L} 1 \times \mathrm{T} 3$ & $-3.28^{* *}$ & $-6.42^{* *}$ & $-7.22^{* *}$ & $-2.57^{* *}$ & $-2.37^{* *}$ & $-3.55^{* *}$ & $-8.85^{* *}$ & $-21.08^{* *}$ & \multicolumn{2}{|c|}{$11.07^{* *}$} \\
\hline $\mathrm{L} 2 \times \mathrm{T} 1$ & $-10.26^{* *}$ & $-2.96^{* *}$ & $-23.51^{* *}$ & $-17.38^{* *}$ & $-5.03^{* *}$ & -11.05 & $-11.15^{* *}$ & $-3.60^{* *}$ & \multicolumn{2}{|c|}{$1.55^{* *}$} \\
\hline $\mathrm{L} 2 \times \mathrm{T} 2$ & $-5.83^{* *}$ & $-11.03^{* *}$ & $-9.04^{* *}$ & $-6.44^{* *}$ & $-1.68^{* *}$ & $-2.83^{* *}$ & $-7.03^{* *}$ & $-1.78^{* *}$ & \multicolumn{2}{|c|}{$6.17^{* *}$} \\
\hline $\mathrm{L} 2 \times \mathrm{T} 3$ & $19.31^{* *}$ & $41.03^{* *}$ & $73.04^{* *}$ & $33.58^{* *}$ & $15.36^{* *}$ & $24.11^{* *}$ & $14.11^{* *}$ & $55.34^{* *}$ & \multicolumn{2}{|c|}{$-22.60^{* *}$} \\
\hline $\mathrm{L} 3 \times \mathrm{T} 1$ & $-12.03^{* *}$ & $-4.61^{* *}$ & $-16.09^{* *}$ & $13.88^{* *}$ & $-7.20^{* *}$ & $-5.02^{* *}$ & $-4.96^{* *}$ & $-8.22^{* *}$ & \multicolumn{2}{|c|}{$4.22^{* *}$} \\
\hline $\mathrm{L} 3 \times \mathrm{T} 2$ & $-1.83^{* *}$ & $-2.90^{* *}$ & $-2.55^{* *}$ & $-3.76^{* *}$ & $-3.90^{* *}$ & $-7.14^{* *}$ & $-15.0^{* *}$ & $-6.05^{* *}$ & \multicolumn{2}{|c|}{$21.03^{* *}$} \\
\hline L3 $\times \mathrm{T} 3$ & $21.76^{* *}$ & $18.03^{* *}$ & $49.62^{* *}$ & $62.31^{* *}$ & $26.24 * *$ & $21.07^{* *}$ & $9.06^{* *}$ & $34.78^{* *}$ & \multicolumn{2}{|c|}{$-18.04^{* *}$} \\
\hline L4 XT1 & $-3.67^{* *}$ & $-10.32^{* *}$ & $-16.45^{* *}$ & $-23.73^{* *}$ & $-1.57^{* *}$ & $-4.77^{* *}$ & $-4.12^{* *}$ & $-3.57^{* *}$ & \multicolumn{2}{|c|}{$2.56^{* *}$} \\
\hline $\mathrm{L} 4 \times \mathrm{T} 2$ & $-15.63^{* *}$ & $-8.45^{* *}$ & $-4.93^{* *}$ & $-8.12^{* *}$ & $-2.49^{* *}$ & $-2.05^{* *}$ & $-1.96^{* *}$ & $-2.74^{* *}$ & \multicolumn{2}{|c|}{$1.73^{* *}$} \\
\hline $\mathrm{L} 4 \times \mathrm{T} 3$ & $17.02^{* *}$ & $21.08^{* *}$ & $34.82^{* *}$ & $25.78^{* *}$ & $10.06^{* *}$ & $19.23^{* *}$ & $18.28^{* *}$ & $10.03^{* *}$ & \multicolumn{2}{|c|}{$-42.07^{* *}$} \\
\hline $\mathrm{L} 5 \times \mathrm{T} 1$ & $40.06^{* *}$ & $14.23^{* *}$ & $13.75^{* *}$ & $18.72^{* *}$ & $14.06^{* *}$ & $34.14^{* *}$ & $6.87^{* *}$ & $9.44^{* *}$ & \multicolumn{2}{|c|}{$-10.70^{* *}$} \\
\hline $\mathrm{L} 5 \times \mathrm{T} 2$ & $-2.59^{* *}$ & $-12.11^{* *}$ & $-10.0^{* *}$ & $-3.29^{* *}$ & $-12.04^{* *}$ & $-10.17^{* *}$ & $-3.86^{* *}$ & $-1.41^{* *}$ & $5.42^{* *}$ & \\
\hline $\mathrm{L} 5 \times \mathrm{T} 3$ & $-74.15^{* *}$ & $-57.31^{* *}$ & $-81.83^{* *}$ & $-99.20^{* *}$ & $-37.78^{* *}$ & $-66.82^{* *}$ & $-3.07^{* *}$ & $-68.05^{* *}$ & $51.14^{* *}$ & \\
\hline LSD 0.05 & 1.17 & 1.28 & 1.29 & 1.55 & 1.04 & 0.79 & 1.23 & 0.96 & 0.83 & \\
\hline 0.01 & 1.65 & 1.82 & 1.83 & 2.43 & 1.51 & 1.03 & 1.68 & 1.32 & 1.27 & \\
\hline
\end{tabular}

(Tanou et al. 2009). A decline in CAT activity has been observed under many stressful conditions (Radotic et al. 2000; Sharma and Dubey 2005). Figure 4 shows additional two major bands for the first 10 rice genotypes under drought stress conditions through PPO analysis. PPO new bands may be due to the induction of new compounds under drought stress conditions that regulate the activity of the antioxidant enzymes. The appearance of new isozyme bands may be used as a biochemical marker to differentiate drought-tolerant genotypes under drought stress conditions. Overall, the activation or inhibition of stress isozymes is combined with ROS level with quantitative changes in enzyme levels which observed intensities and number of isozyme bands under stress conditions 


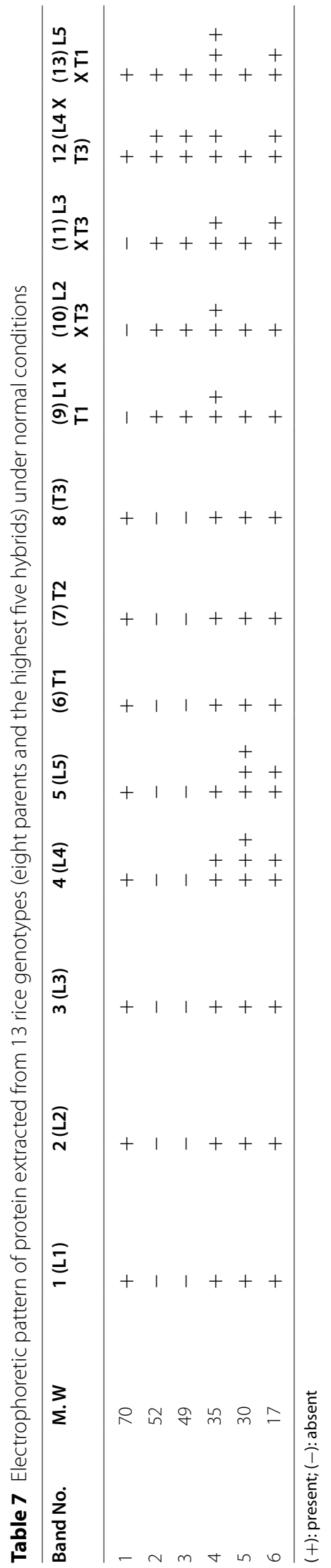




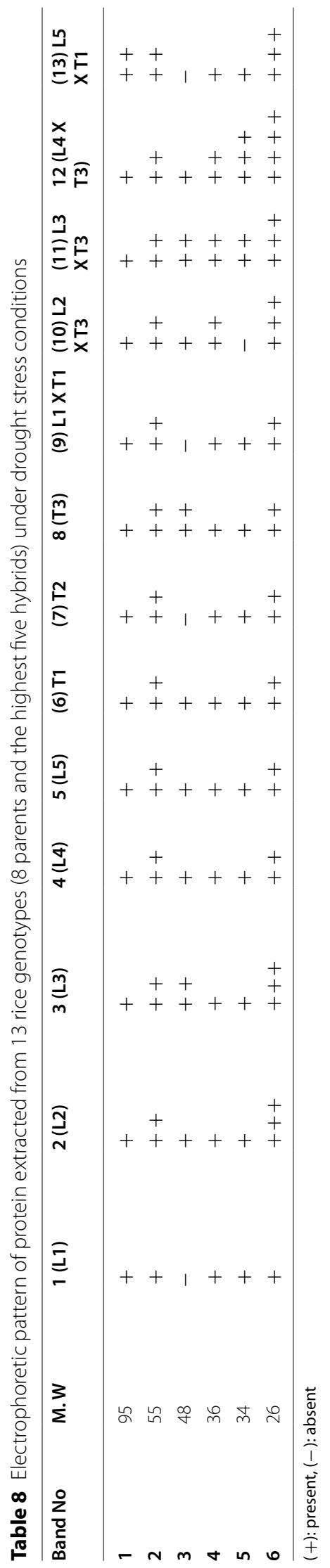




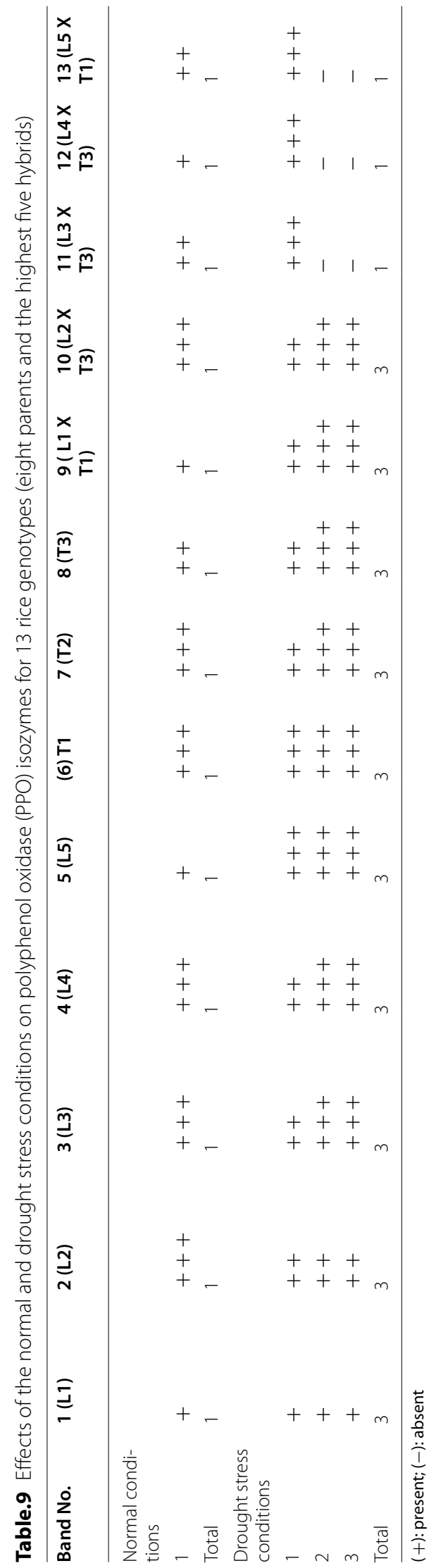




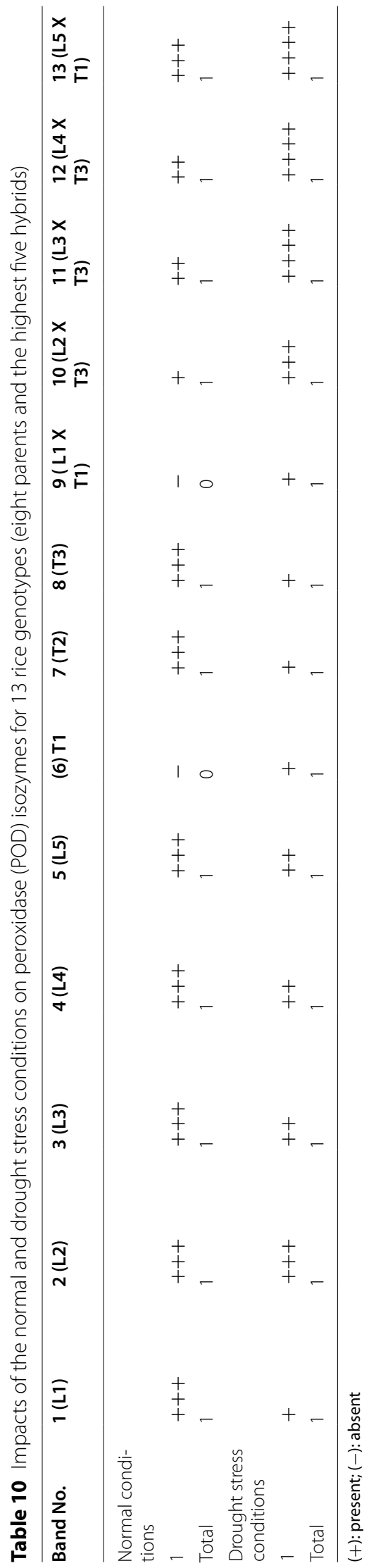


(El-Mouhamady et al. 2020). Figure 6 shows the appearance of new POD bands and the increase in thickness of other bands under drought stress conditions. This may be considered as a response to drought stress conditions, leading to the enzymatic removal of $\mathrm{H}_{2} \mathrm{O}_{2}$ by POD (Abedi and Pakniyat 2010). Moreover, the band thickness also showed the resistance of the plants under drought stress. The drought stress will help in the hydrolysis that can result in the toxic compounds, which causes the inhibition of enzymatic activities (Mahajan and Tuteja 2005). Plants were able to neutralize the toxic compounds through the osmotic adjustment of cells, so the formed bands were thicker during the increase in drought stress levels (Herwibawa et al. 2014).

\section{Conclusions}

This study aimed to improve water stress tolerance in rice through the use of traditional plant breeding programs and biochemical and molecular genetic studies. Also, this research examined the evaluation of a large number of field and physiological traits under normal and drought conditions. Line $\mathrm{X}$ tester analysis and its parameters were the most important genetic parameters evaluated for all studied attributes under both conditions. The final results revealed that the rice genotypes (T1, T2, T3, L1 X T1, L2 X T3, L3 X T3, L4 X T3, L5 X T1) recorded high level of water stress tolerance depending on all genetic parameters data obtained in all studied traits under drought experiment compared to the normal treatment. Besides, biochemical and molecular markers results proved the existence of molecular and biochemical genetic evidence of drought tolerance in the previous genotypes through enhancing the activities of peroxidase (POD) and polyphenol oxidase (PPO) under water-deficit conditions which confirmed the tolerance of water-deficit stress in the eight rice genotypes and the best five F1 crosses.

\footnotetext{
Abbreviations

1: Line 1 or Sakha 101; 2: Line 2 or Sakha 102; 3: Line 3 or Sakha 103,; 4: Line 4 or Giza 172; 5: Line 5 or Giza 177; 6: Tester 1 or GZ1364-S-5-4; 7: Tester 2 or Agami; 8: Tester 3 or Gaori; 9: Line 1 X tester 1 or Sakha 101 X GZ1368-S-5-4; 10: Line $2 X$ tester 3 or Sakha $102 X$ Gaori; 11: Line 3 X tester 3 or Sakha 103 X Gaori; 12: Line 4 X tester 3 or Giza 172 X Gaori; 13: Line 5 X tester 1 or Giza 177 X GZ1368-S-5-4; L.S.D: Least significant difference.
}

\section{Supplementary Information}

The online version contains supplementary material available at https://doi. org/10.1186/s42269-021-00656-1.

Additional file 1. Important supplementary data.

\section{Acknowledgements}

Not applicable.

\section{Authors' contributions}

ABAE done the part of plant breeding, including sowing, hybridization and statistical analysis, written this part, reviewed the article before publication and submitted the manuscript to the journal. AMG done the part of protein electrophoretic pattern and written this part. GSAA done the part of antioxidant enzymes activity and written this part. All authors read and approved the final manuscript.

\section{Funding}

Not applicable.

\section{Availability of data and materials}

The authors announce that the data supporting the results of this study are existing within the article.

\section{Declarations}

Ethics approval and consent to participate Not applicable.

\section{Consent for publication \\ Not applicable.}

\section{Competing interests}

The authors declare that they have no competing interests.

\section{Author details}

${ }^{1}$ Genetics and Cytology Department, Biotechnology Research Institute, National Research Centre, 33 El Buhouth ST, Cairo 12622, Dokki, Egypt.

${ }^{2}$ Molecular Biology Department, Biotechnology Research Institute, National Research Centre, 33 El Buhouth ST, Cairo 12622, Dokki, Egypt.

Received: 1 July 2021 Accepted: 6 November 2021

Published online: 04 January 2022

\section{References}

Abdel Sattar AA, El-Mouhamady AA (2012) Genetic analysis and molecular markers for yield and its components traits in faba bean (Vicia Faba L.). Aus J of Basic \& Applied Sci 6:458-466

Abedi T, Pakniyat H (2010) Antioxidant enzyme changes in response to drought stress in ten cultivars of oilseed rape (Brassica napus L.). Czech J Genet Plant Breed 46:27-34

Abo-Hamed SA, El-Mouhamady AA, Madkour MA (2016) Study the resistance of water shortage in wheat through root traits and half diallel analysis under normal and drought conditions. J of Enviro Sci 45:247-253

Ahmadi SAK, Ebadi A, Jahanbakhsh S, Daneshian J, Siadat SA (2015) Changes in enzymatic and nonenzymatic antioxidant defense mechanisms of canola seedlings at different drought stress and nitrogen levels. Turkish J of Agric and Fore 39:601-612

Al-Kordy MA, Ibrahim HM, El-Mouhamady AA, Abdel-Rahman HM (2019) Genetic stability analysis and molecular depiction in elite entries of rice (Oryza Sativa L.). Bull of the Nat Res Cen 43:1-15

Ashraf M (2009) Biotechnological approach of improving plant salt tolerance using antioxidants as markers. Biotech Adva 27:84-93

Bozin B, Mimica-Dukic N, Samojlik I, Goran A, Igic R (2008) Phenolics as antioxidants in garlic (Allium sativum L., Alliaceae). Food Chem 111:925-929

Bradford MM (1976) A rapid and sensitive method for the quantitation of microgram quantities of protein utilizing the principle of protein-dye binding. Anal Biochem 72:248-254

Brown AHD (1978) Isozymes, plant population genetic structure and genetic conservation. Theo and App Gen 52:145-157

Childs RE, Bardsley WG (1975) Steady-state kinetics of peroxidase with 2,2'-azinodi-(3-ethyl-benzthiazoline6-sulphonic acid) as chromogen. Bioch J 145:93-103

El- Demardash IS, El-Mouhamady AA, Abdel- Rahman HM, Elewa TA, Aboud KA (2017) Using gamma rays for improving water deficit tolerance in rice. Cur Sci Int 6:321-327 
El-Beltagi HS, Mohamed AA, Rashed MM (2010) Response of antioxidative enzymes to cadmium stress in leaves and roots of radish. Notu Scientia Biolo 2:76-82

Eldessouky ELS, Heiba SAA, El-Mouhamady AA, Abdel-Tawab YM (2016) DNA fingerprinting and half diallel analysis of some rice genotypes under water deficit conditions. RJPBCS 7:985-997

El-Keredy MS, Draz AE, Ragab AY, Abdallah AA, El-Mouhamady AA (2003a) Combining ability for some quantitative characters in rice (Oryza sativa L.) under normal and saline soil conditions. Tenth Conf Agro Octo Suez Canal Univ El-Irish Egypt 9:7-10

El-Keredy MS, Draz AE, Ragab AY, Abdallah AA, El-Mouhamady AA (2003b). Effect of different levels of salinity on some agronomic, yield and its components and grain quality characters in rice. Proc $10^{\text {th }}-$ The tenth conf. of agro. Octo. Suez Canal Univ. Fac. Environ. Agric Sci El-Irish Egypt: 80-89

El-Keredy MS, Draz AE, Ragab AY, Abdallah AA, El-Mouhamady AA (2003C) Studies on rice 9Oryza Sativa L.) II. Genetical analysis and correlation coefficients in some chemical and grain yield and its components characters in rice under saline soil conditions. In: Proceedings of the10th the tenth conf. of agro. Octo. Suez Canal Univ. Fac. Environ. Agric Sci El-Irish Egypt: 121-132

El-Mouhamady (2003) Breeding studies for Salt Tolerance in rice. Ph.D Thesis Tan Uni Bra Kafr-She Fac Agric Egypt

El-Mouhamady (2009) Breeding for drought tolerance in rice. Ph.D Thesis Fac Agric Kafr-Shei Univ Egypt

El-Mouhamady AA, Abd-El-Aal SKH, Elewa TA, Aboud KA (2015) Studies on the biotic stress resistance in rice through molecular markers and six population analysis. Int JCurr Microbiol App Sci 4:831-854

El-Mouhamady AA, Abdel-Rahman HM, Rizkalla AA, El-Metwally MA (2019) Assessment of water stress tolerance in wheat genotypes based on half diallel analysis and DNA fingerprinting. Pak J of Biol Sci 22:103-116

El-Mouhamady AA, Amer KhA, Ragab AY (2012a) a) Development of salinity tolerance in some genotypes of barley using line $X$ tester analysis and some techniques of biotechnology. J of Appl Sci Res 8:972-982

El-Mouhamady AA, El-Ashary ZM, Mohamed Fl, Elewa TA, Aboud KA (2016) Study the effect of water stress conditions on some genotypes of bread Wheat (Triticum aestivum L.) based on morphological, physiological traits and DNA fingerprinting. RJPBCS 5:2065-2077

El-Mouhamady AA, El-Demardash IS, Aboud KA (2010) Biochemical and molecular genetic studies on rice tolerance to salinity. J of Ame Sci 6:521-535

El-Mouhamady AA, El-Ekhtyar AM, El-Demardash IS (2012b) Molecular markers linked to some traits in rice. J of Appl Sci Res 8:2689-2699

El-Mouhamady AA, El-Ekhtyar AM, Zayed BA (2011) Molecular genetic studies on sterility and fertility traits in rice under egyptian conditions. Faculty of Science, Zagazig University., 6Th Envir Conf 59-68

El-Mouhamady AA, El-Metwally MA (2020) Appreciation of genetic parameters and molecular characterization in some promising accessions of soybean (Glycine max L.). Pak J of Biol Sci 23:425-438

El-Mouhamady AA, El-Seidy EH, Aboud KA (2012C) Identification of a molecular markers linked to drought tolerance in some genotypes of barley. Aust J of Basic and Applied Sci 6(5):196-204

El-Mouhamady AA, El-Seidy EH, El-Ekhtyar AM, Elewa TA (2014a) Molecular markers and physiological traits linked to salinity tolerance in rice. Int J of Acad Res Part A 6:195-205

El-Mouhamady AA, Gad AM, Abdel Karim GSA (2020) Genetic Amelioration in lentil (Lens culinaris L.) using different doses of ethyl methane sulphonate. Bull of the Nati Res Cen 44:88-102

El-Mouhamady AA, Gad AM, Abdel Karim GSA, Abdel-samea NS, Habouh MAF (2021b) Biochemical and molecular genetic markers associated with salinity tolerance in flax (Linum usitatissimum L.). Annals of R.S.C.B 25: 4828-4844

El-Mouhamady AA, Gad AM, Habouh MAF (2021 b) Determination of genetic parameters associated with salt stress tolerance in canola based on scot markers and protein pattern analysis. Asian J Plant Sci 20:534-554. https://doi.org/10.3923/ajps.2021.534.554

El-Mouhamady AA, Habouh MAF (2019) Genetic improvement of some rice genotypes for salinity tolerance using generation mean analysis. Cu Sci Int 8:321-348

El-Mouhamady AA, Ibrahim HF (2020) Elicitation of salt stress-tolerant mutants in bread wheat (Triticum aestivum $\mathrm{L}$.) by using gamma radiation. Bull of the Nat Res Cen 44:1-18
El-Mouhamady AA, Rady MR, El-Seidy EH (2014b) Assessment of genetic variability for six lines of wheat using physiological traits and molecular markers technique under normal irrigation and water stress conditions. W Appli Sci J 29:506-516

El-Sayed AA, El-Hity MA, Abdallah AA, Abd-ella HE (2018) Role of some growth characters in improving the drought tolerance in rice. J Plant Prod Mans Univ 9:757-764

ElSayed Al, El-hamahmy MAM, Rafudeen MS, Mohamed AH, Omar AA (2019) The impact of drought stress on antioxidant responses and accumulation of flavonolignans in milk thistle (Silybum marianum (L.) Gaertn). Plants 8:611-628

El-Seidy EH, El-Mouhamady AA, Aboud KA (2013) Studies on the modification of gene expression which responsible for salinity tolerance in some genotypes of wheat. Int J of Acad Res Part A 5:23-32

Esmail RM, Abdel Sattar AA, Abdel-samea NS, El-Mouhamady AA, Abdelgany EM, Fathallaha FB (2016) Assessment of genetic parameters and drought tolerance indices in maize diallel crosses. Res J Pharm Biol Chem Sci 7:2409-2428

Farid MA, Abou Shousha AA, Negm MEA, Shehata SM (2016) Genetical and Molecular studies on salinity and drought tolerance in rice (Oryza Sativa L.). J Agric Res Kafr El-Sheikh Univ 42:1-23

Farshadfar E, Ghasempour H, Vaezi H (2008) Molecular aspects of drought tolerance in bread wheat (T. aestivum). Pak J Biol Sci 11:118-112

Feki K, Tounsi S, Brini F (2017) Comparison of an antioxidant system in tolerant and susceptible wheat seedlings in response to salt stress. Span J of Agric Res 15:e0805-e0815

Foyer C, Noctor G (2003) Redox sensing and signaling associated with reactive oxygen in chloroplasts, peroxisomes and mitochondria. Physiol Plant 119:355-364

Gunes A, Pilbeam D, Inal A, Coban S (2008) Influence of silicon on sunflower cultivars under drought stress, I: growth, antioxidant mechanisms and lipid peroxidation. Commun Soil Sci Plant Nutr 39:1885-1903

Habig WH, Pabst MJ, Jakoby WB (1974) Glutathione transferases: the first enzymatic step in mercapturic acid formation. J Biol Chem 249:7130-7139

Heiba SAA, Eldessouky SEI, El-Mouhamady AA, El-Demardash IS, AbdelRaheem AA (2016a) Use of RAPD and ISSR assays for the detection of mutation changes in wheat (Triticumaestivium L.) DNA induced by ethyl-methane sulphonate (EMS). Int J of Chem Tech Res 9:42-49

Heiba SAA, El-Mouhamady AA, Eldessouky SEI, Ali HBM, Elewa TA (2016 a) Study the genetic variations related to the resistance of heavy metals toxicity in some rice genotypes using RAPD markers. Int J Curr Micro App Sci 5: 174-189 http://www.ijcmas.com

Hellal F, El-Sayed S, Gad AA, Abdel Karim G, Abdelly C (2020) Antitranspirants application for improving the biochemical changes of barely under water stress. I J Agric Sci 51:287-298

Herwibawa B, Haryanto TAD, Sakhidin, (2014) Peroxidase isozyme identification of some rice genotypes in $\mathrm{M} 1$ generation under drought stress level of-0.03 MPa. Agrivita 36:210-216

IRRI (2005) IRRISTAT for Windows. V6 Manila, Philippines. Int Rice Res Insti

Kar M, Mishra D (1976) Catalase, peroxidase and polyphenol oxidase during rice leaf senescene. Plant Physiol 57:315-319

Kempthorne O (1957) An introduction to genetic statistics. Wiley, New York

khatab IA, El-Mouhamady AA, Abdel-Rahman HM, Farid MA, El-Demardash IS, (2017) Agro-morphological and molecular characterization of sorghum (Sorghum Vulgare L.) for water stress tolerance. Int J Cur Res Biosci Plant Biol 4:37-55

Khatab IA, El-Mouhamady AA, Mariey SA, Elewa TA (2019) Assessment of water deficiency tolerance indices and their relation with ISSR markers in barley (Hordeum vulgare L.). Cu Sci Int 8:83-100

Khatab IA, El-Mouhamady AA, Mariey SA, El-Hawary MM, Habouh MAF (2021) Molecular evaluation and identification of some barley hybrids tolerant to salt stress. Pak J Biol Sci 24:997-1014. https://doi.org/10. 3923/pjbs.2021.997.1014

Kim Y, Chung YS, Lee E, Tripathi P, Heo S, Kim KH (2020) Root response to drought stress in rice (Oryza Sativa L.). Int J Mol Sci 21:1-22. https://doi. org/10.3390/ijms21041513www

Kishk AMS, Abdel-Rahman HM, El-Mouhamady AA, Aboud KA (2017) Sophisticated genetic studies on onion through using gamma rays. Res J Pharm Biol \& Chem Sci 8:202-220 
Laemmli UK (1970) Cleavage of structural proteins during the assembly of the head of bacteriophage T4. Nature 227:680-685

Mahajan S, Tuteja N (2005) Cold, salinity, and drought stresses: an overview. Arch Biochem Biophys 444:139-158

Manchenko G (2002) Handbook of detection of enzymes on electrophoretic gels. CRC Press Boca Raton. https://doi.org/10.1201/9781420040531

Melandri G, AbdElgawad H, Riewe D, Hageman JA, Asard H, Beemster GTS, Kadam N, Jagadish K, Altamann T, Spira CR, Bouwmeester H (2020) Biomarkers for grain yield stability in rice under drought stress. J Exp Bot 71:669-683

Mittler R (2017) ROS are good! Trends Plant Sci 22:11-19

Moradpour K, Najaphy A, Mansoorifar S, Mostafaie A (2014) Evaluation of leaf protein pattern in wheat genotypes under drought stress. Int J Adva Biol Biomed Res 2:840-846

Morgan JM (1980) Osmotic adjustment in the spikelets and leaves of wheat. J Exp Bot 31:655-665

Mwando E, Han Y, Angessa TT, Zhou G, Hill CB, Zhang XG, Li C (2020) Genomewide association study of salinity tolerance during germination in barley (Hordeum vulgare L). Front Plant Sci 11:1-15

Najaphy A, Moradpour K, Mansourifar C, Mostafaie A (2014) Terminal drought induced changes in leaf protein pattern of wheat. Int J Plant Anim Enviorn Sci 4:23-26

Najaphy A, Niari Khamssi N, Mostafaei MH (2010) Effect of progressive water deficit stress on proline accumulation and protein profiles of leaves in chickpea. Afr J Biot 9:7033-7036

Nakabayashi R, Saito K (2015) Integrated metabolomics for abiotic stress responses in plants. Cur Opin Plant Biol 24:10-16

Noctor G, Mhamdi A, Foyer CH (2014) The roles of reactive oxygen metabolism in drought: not so cut and dried. Plant Phys 164:1636-1648

Oono Y, Seki M, Satou M, lida K, Akiyama K, Sakurai T, Fujita M, Yamaguchi-Shinozaki K, Shinozaki K (2006) Monitoring expression profiles of Arabidopsis genes during cold acclimation and deacclimation using DNA microarrays. Funct Integr Genomics 6:212-234

Pan Y, Wu LJ, Yu ZL (2006) Effect of salt and drought stress on antioxidant enzymes activities and SOD isoenzymes of liquorice (Glycorhiza uralensis Fisch). J Plant Growth Reg 49:157-165

Radotic K, Ducic T, Mutavdzic, (2000) Changes in peroxidase activity and isozymes in spruce needles after exposure to different concentrations of cadmium. Environ Exp Bot 44:105-113

Ramadan WA, Abdel-Rahman HM, El-Mouhamady AA, Habouh MAF, Aboud KA (2016) Molecular genetic studies on some barley entries for drought tolerance. Int J Pharm Tech Res 9:265-285

Reddy AM, Kumar SG, Jyothsnakumari G, Thimmanaik S, Sudhakar C (2005) Lead induced changes in antioxidant metabolism of horsegram (Macrotyloma uniflorum (Lam.) Verdc.) and bengalgram (Cicer arietinum L.). Chemosphere 60:97-104

Reshma A, Raja RV, Latha P (2020) Influence of drought stress on leaf protein pattern of maize genotypes. Int J Chem Sturuct 8:245-247

Rodziewicz P, Chmielewska K, Sawikowska A, Marczak T, Łuczak M, Bednarek P, Mikołajczak K, Ogrodowicz P, Kuczyńska A, Krajewski P, Stobiecki M (2019) Identification of drought responsive proteins and related proteomic QTLs in barley. J Exp Bot 70:2823-2837

Roxas VP, Lodhi SA, Garrett DK, Mahan JR, Allen RD (2000) Stress tolerance in transgenic tobacco seedlings that overexpress glutathione S-transferase/ glutathione peroxidase. Plant Cell Phys 41:1229-1234

Sadiya S (2020) Morphological analysis of drought tolerance traits in rice (Oryza Sativa L.). Acta Sci Agric 4:1-9

Shafina H, Roy P, Anandan A, Samantaray S, Pradhan SK, Singh ON (2015) Genetic diversity study of seed proteins in rice drought tolerant donar accessions. Crop Improv Div Cent Rice Res Inst 6:105-376

Sharma P, Dubey RS (2005) Drought induces oxidative stress and enhances the activities of antioxidant enzymes in growing rice seedlings. Plant Growth Reg 46:209-221

Sharma R, Sahoo A, Devendran R, Jain M (2014) Over-expression of a rice tau class glutathione S-transferase gene improves tolerance to salinity and oxidative stresses in Arabidopsis. PloS ONE 9: e92900

Singh SP, Kumar A, Satyendra KM, Nahakpam S, Sinha S, Smirty SP, Kumar S, Singh PK (2018) Identification of drought tolerant rice (Oryza sativa L.) genotypes using drought tolerance indices under normal and water stress condition. Int J Curr Microbiol Appl Sci 7:4757-4766
Stegemann H, Afify AMR, Hussein KRF (1985) Cultivar identification of dates (Phoenix dactylifera) by protein patterns. In: Second international symposium of biochemical approaches to identification of cultivars, Braunschweing West Germany p. 44

Studier FW (1973) Analysis of bacteriophage T7 early RNAs and proteins on slab gels. J Mol Bio 79:237-242

Suzuki N, Koussevitzky S, Mittler R, Miller G (2012) ROS and redox signalling in the response of plants to abiotic stress. Plant Cell Environ 35:259-270

Tanou G, Molassiotis A, Diamontidis G (2009) Induction of reactive oxygen species and necrotic death-like destruction in strawberry leaves by salinity. Environ Exp Bot 65:270-281

Tawfik RS, El-Mouhamady AA (2019) Molecular genetic studies on abiotic stress resistance in sorghum entries through using half diallel analysis and inter-simple sequence repeat (ISSR) markers. Bull Nat Res Cen 43:1-17. https://doi.org/10.1186/s42269-019-0155-1

Verslues PE, Juenger TE (2011) Drought, metabolites, and Arabidopsis natural variation: a promising combination for understanding adaptation to water-limited environments. Curr Opin Plant Bio 14:240-245

Virmani SS, Viraktamath BC, Cassal CL, Toledo RS, Lopez MT, Manalo JO (1997) Hybrid rice breeding manual. Int Rice Res Inst

Weng M, Cui L, Liu F, Zhang M, Shan L, Yang S, Deng X (2015) Effects of drought stress on antioxidant enzymes in seedlings of different wheat genotypes. Pak J Bot 47:49-56

Wyanne JC, Emery DA, Rice PW (1970) Combining ability estimates in Arachis hypogea L. II- Field Performance of F1 hybrids. Crop Sci 10

Yang RY, Tsou SCS, Lee TC, Chang LC, Kuo G, Lai PY (2006) Moringa, a novel plant rich in antioxidants, bioavailable iron, and nutrients. In: Ho CT (ed) Chall in Chem and Bio of Herbs 224-239

Yang X, Wang B, Chen L, Li P, Cao C (2019) The different influence of drought stress at the flowering stage on rice physiological traits, grain yield and quality. Sci Rep 9:3742. https://doi.org/10.1038/s41598-019-40161-0

Zian AH, El-Demardash IS, El-Mouhamady AA, El-Barougy E (2013) Studies the resistance of lupine for fusarium oxysporum F. spLupini) through molecular genetic technique. World Appl Sci J 26:1064-1069

\section{Publisher's Note}

Springer Nature remains neutral with regard to jurisdictional claims in published maps and institutional affiliations.

\section{Submit your manuscript to a SpringerOpen ${ }^{\circ}$ journal and benefit from:}

- Convenient online submission

- Rigorous peer review

- Open access: articles freely available online

- High visibility within the field

Retaining the copyright to your article

Submit your next manuscript at springeropen.com 